\title{
High summertime aerosol organic functional group concentrations from marine and seabird sources at Ross Island, Antarctica, during AWARE
}

\author{
Jun Liu ${ }^{1}$, Jeramy Dedrick ${ }^{1, a}$, Lynn M. Russell ${ }^{1}$, Gunnar I. Senum ${ }^{2}$, Janek Uin ${ }^{2}$, Chongai Kuang ${ }^{2}$, \\ Stephen R. Springston ${ }^{2}$, W. Richard Leaitch ${ }^{3}$, Allison C. Aiken ${ }^{4}$, and Dan Lubin ${ }^{1}$ \\ ${ }^{1}$ Scripps Institution of Oceanography, University of California, San Diego, 9500 Gilman Drive, \\ La Jolla, CA 92093, USA \\ ${ }^{2}$ Environmental \& Climate Sciences Department, Brookhaven National Laboratory, Building 815-E, \\ Upton, NY 11973-5000, USA \\ ${ }^{3}$ Environment and Climate Change Canada (ECCC), Toronto, ON, Canada \\ ${ }^{4}$ Earth and Environmental Science, Earth Systems Observations, Los Alamos National Laboratory, \\ Los Alamos, New Mexico, USA \\ ${ }^{a}$ now at: Texas A\&M University, 400 Bizzell St, College Station, TX 77843, USA
}

Correspondence: Lynn M. Russell (lmrussell@ucsd.edu)

Received: 27 December 2017 - Discussion started: 12 January 2018

Revised: 26 May 2018 - Accepted: 29 May 2018 - Published: 18 June 2018

\begin{abstract}
Observations of the organic components of the natural aerosol are scarce in Antarctica, which limits our understanding of natural aerosols and their connection to seasonal and spatial patterns of cloud albedo in the region. From November 2015 to December 2016, the ARM West Antarctic Radiation Experiment (AWARE) measured submicron aerosol properties near McMurdo Station at the southern tip of Ross Island. Submicron organic mass (OM), particle number, and cloud condensation nuclei concentrations were higher in summer than other seasons. The measurements included a range of compositions and concentrations that likely reflected both local anthropogenic emissions and natural background sources. We isolated the natural organic components by separating a natural factor and a local combustion factor. The natural OM was 150 times higher in summer than in winter. The local anthropogenic emissions were not hygroscopic and had little contribution to the CCN concentrations. Natural sources that included marine sea spray and seabird emissions contributed 56\% OM in summer but only $3 \%$ in winter. The natural OM had high hydroxyl group fraction ( $55 \%), 6 \%$ alkane, and $6 \%$ amine group mass, consistent with marine organic composition. In addition, the Fourier transform infrared (FTIR) spectra showed the natural sources of organic aerosol were characterized by amide
\end{abstract}

group absorption, which may be from seabird populations. Carboxylic acid group contributions were high in summer and associated with natural sources, likely forming by secondary reactions.

\section{Introduction}

West Antarctica is one of the most rapidly warming regions on Earth (Bromwich et al., 2013), which has potential impacts for the melting of the Antarctic ice sheets and consequent sea level rise (Steig et al., 2009; Lambeck et al., 2002). In some regions, ambient aerosols contribute substantially to the radiation balance (IPCC, 2013), but little is known about the sign and magnitude of their contribution in Antarctica because of the lack of measurements of their abundance, composition, and sources. In fact, there are few places on Earth where measurements of aerosols and their properties are needed to constrain modeled radiation as much as in Antarctica.

McMurdo Station is the only site with measurements of PM (particulate matter), elemental carbon, organic carbon, and number concentrations that is within $300 \mathrm{~km}$ of the Ross 
Ice Shelf (which covers an area of more than $500000 \mathrm{~km}^{2}$ ). Furthermore, the station is unique in that McMurdo Station is one of the two sites that have published aerosol measurements starting in 1968, with the other one being the Amundsen Scott Station at the South Pole. The site has at least 10 publications describing aerosol measurements over the past 50 years, most of which were limited to summer (Cadle et al., 1968; Warburton, 1973; Ondov et al., 1973a; Hogan, 1975; Hofmann, 1988; Hansen et al., 2001; Mazzera et al., 2001a, b; Giordano et al., 2017; Kalnajs et al., 2013; Khan et al., 2018). No stations in Antarctica measured inorganic chemical composition year-round until 1978 (Parungo et al., 1981), and none have measured year-round organic components. In 1966, electron micrographs of particles collected on a four-stage impactor provided some of the first aerosol measurements carried out at McMurdo Station (Cadle et al., 1968). Filter samples were collected for elemental analysis in 1970-1971 (Ondov et al., 1973b). During the austral summers of 1969 and 1970, the Aitken nuclei concentration was reported to be $\sim 1000 \mathrm{~cm}^{-3}$ (Warburton, 1973). In another study, the number concentration was 50 to $150 \mathrm{~cm}^{-3}$ with continental winds and $\sim 300 \mathrm{~cm}^{-3}$ with maritime winds (Hogan, 1975). Balloon measurements were conducted later for stratospheric aerosols, and long-distance signals from volcanic sources in tropical areas were found in the stratosphere (Hofmann et al., 1986; Solomon et al., 1994). Hansen et al. (2001) measured black carbon at McMurdo in austral summer in 1995-1996. Another study (Mazzera et al., 2001b) reported more detailed $\mathrm{PM}_{10}$ elemental composition, elemental and organic carbon, and nitrate concentrations for 1995-1996 and 1996-1997 at McMurdo. Chemical mass balance $(\mathrm{CMB})$ receptor modeling estimated that soil dust, sea salt, combustion emissions, sulfates, methanesulfonate, and nitrates contributed 57, 15, 14, 10, 3, and $1 \%$, respectively, to the summertime $\mathrm{PM}_{10}$ mass (Mazzera et al., 2001a). Kalnajs et al. (2013) showed that ozone depletion is correlated to aerosol concentrations because halogencontaining aerosol consumed ozone. An aerosol mass spectrometer (AMS) at a site $20 \mathrm{~km}$ northeast from McMurdo Station during October to December 2014 and August to October 2015 (Giordano et al., 2017) found sulfate accounted for more than $50 \%$ of nonrefractory composition. Many measurement campaigns were limited to austral summer months because of restrictions on access (Cadle et al., 1968; Ondov et al., 1973a; Warburton, 1973) and so lack information on seasonal changes.

The few year-round aerosol concentration and composition measurements in Antarctica were collected at several sites in coastal Antarctica (all of which are more than $1500 \mathrm{~km}$ from McMurdo Station) (Hara et al., 2005; Wagenbach et al., 1998; Jourdain and Legrand, 2002; Gras, 1993; Hara et al., 2004, 2010; Weller et al., 2013; Minikin et al., 1998; Read et al., 2008) and at several sites on the Antarctic Peninsula (more than $3000 \mathrm{~km}$ from McMurdo Station) (Asmi et al., 2018; Mishra et al., 2004; Kim et al., 2017;
Saxena and Ruggiero, 1990; Savoie et al., 1993; Loureiro et al., 1992), as well as at the South Pole (more than $1000 \mathrm{~km}$ from McMurdo Station) (Hansen et al., 1988; Bodhaine et al., 1986; Harder et al., 2000; Parungo et al., 1981; Bodhaine, 1983; Hogan and Barnard, 1978) and at Dome C (more than $1000 \mathrm{~km}$ from McMurdo Station) (Legrand et al., 2017a, b; Udisti et al., 2012). At the South Pole, aerosol particle number concentration ranged from 10 to $30 \mathrm{~cm}^{-3}$ in winter and 100 to $300 \mathrm{~cm}^{-3}$ in summer (Bodhaine, 1983; Parungo et al., 1981; Hogan and Barnard, 1978). This low winter and high summer seasonal difference has also been observed at coastal Antarctic sites, but the average concentrations were typically higher, with summertime concentrations ranging from 300 to $2000 \mathrm{~cm}^{-3}$ and wintertime concentrations from 10 to $200 \mathrm{~cm}^{-3}$ (Kim et al., 2017; Gras, 1993). Consistent with this seasonal difference in particle number concentrations, most summertime non-sea salt sulfate mass concentrations were at least 5 times higher than winter concentrations (Jourdain and Legrand, 2002; Weller and Wagenbach, 2007; Udisti et al., 2012; Legrand et al., 2017a; Asmi et al., 2018), likely because of the contributions from biogenic DMS emissions from the surrounding Southern Ocean. However, most sea salt aerosols had wintertime maximum concentrations with more than 2 times more $\mathrm{Na}^{+}$mass concentrations in winter than summer (Parungo et al., 1981; Wagenbach et al., 1998; Jourdain and Legrand, 2002; Weller and Wagenbach, 2007; Jourdain et al., 2008; Udisti et al., 2012; Legrand et al., 2017a, b; Asmi et al., 2018).

The few hygroscopicity and CCN measurements reported near West Antarctica are also recent and sparse. Defelice et al. (1997) conducted CCN measurements at Palmer Station on the Antarctic Peninsula in January and February 1994. They collected CCN for 27 days at 0.3 and $1 \%$ SS and found $\mathrm{CCN}$ concentration to be between 79 and $158 \mathrm{~cm}^{-3}$. Asmi et al. (2010) found that aerosol particles over the Southern Ocean are very hygroscopic, with a growth factor of 1.75 at $90 \mathrm{~nm}$. At King Sejong Station on King George Island, Kim et al. (2017) found that CCN concentrations are high in summer $\left(\sim 200 \mathrm{~cm}^{-3}\right)$ and low in winter $\left(\sim 50 \mathrm{~cm}^{-3}\right)$. Biological emissions from marine sulfate sources have been proposed to explain a large fraction of CCN in the Southern Ocean region (McCoy et al., 2015). Biological sulfate aerosol accounts for $43-65 \%$ of the summer zonal mean CCN concentrations and $7-20 \%$ of the winter $\mathrm{CCN}$ over the oceans in the Southern Hemisphere, including the circumpolar Southern Ocean (Korhonen et al., 2008). This important role for biological sulfate in the Southern Ocean suggests that biogenic organic components may also contribute significantly to particle number and mass, but measurements of organic particles are too scarce to determine if this is the case (McCoy et al., 2015).

For comparison, in marine and Arctic regions, the organic composition of particles have shown a high fraction of hydroxyl group (61\% of OM for the North Atlantic and $47 \%$ of OM for the Arctic) as well as some alkane and amine 
groups, likely associated with sugars, carbohydrates, and amino sugars that originated from biological materials in seawater (Hawkins and Russell, 2010; Modini et al., 2015; Russell et al., 2010; Frossard et al., 2013; Leaitch et al., 2018; Shaw et al., 2010). Organic nitrogen has also been identified as a tracer component $\left(0.02\right.$ to $\left.10 \mathrm{ng} \mathrm{m}^{-3}\right)$ in aerosol particles in various studies in Antarctic (Schmale et al., 2013; Barbaro et al., 2015b; Dall'Osto et al., 2017) and Arctic (Scalabrin et al., 2012; Dall'Osto et al., 2012) regions. Some of the few measurements of organic aerosol particle composition that have been made in marine and polar regions are those of amino acids, which are summarized in Table S1 in the Supplement (Mace et al., 2003a, b; Kuznetsova et al., 2005; Scalabrin et al., 2012; Barbaro et al., 2015b; Wedyan and Preston, 2008; Shi et al., 2010; Matsumoto and Uematsu, 2005; Mandalakis et al., 2011; Violaki et al., 2010). Amino acids in remote marine and coastal regions have been used as markers for biological activities since they are natural chemical constituents of many marine and terrestrial organisms (Barbaro et al., 2015b; Scalabrin et al., 2012; Milne and Zika, 1993; Cowie and Hedges, 1992). In addition, amino acids contain organic nitrogen and specifically amine groups, which are also consistent with measurements in polar regions of CHNO fragments (Schmale et al., 2013) and amine groups (Shaw et al., 2010; Frossard et al., 2011). Sugar, levoglucosan, phenols and anthropogenic persistent organic compounds were measured in ambient aerosols at Mario Zucchelli Station and Concordia Station (Zangrando et al., 2016; Barbaro et al., 2016, 2017, 2015a). Carboxylic acids with low molecular weights were also measured at Mario Zucchelli Station, Concordia Station, and Dumont d'Urville (Barbaro et al., 2017; Legrand et al., 2012).

The Ross Sea has a surprisingly high biological primary production rate in the summer, making it the most biologically active part of the southern polar region (Arrigo et al., 2008). Seabird emissions were linked to new particle formation (Weber et al., 1998) and to particles containing $\mathrm{CHN}$ and CHNO fragments (Schmale et al., 2013). The CHNO fragments identified by mass spectrometry have been associated with uric acid and other nitrogen-containing components that are produced from penguin guano (Schmale et al., 2013). The ammonia emissions from seabird colonies have also been shown to contribute substantially to atmospheric particle formation and cloud-albedo radiative effects in the Arctic (Croft et al., 2016b). Organic aerosol components were also associated with meltwater ponds in continental Antarctica (Kyrö et al., 2013).

AWARE (ARM West Antarctic Radiation Experiment) provides the most thorough yearlong aerosol and radiative property measurements yet obtained from Antarctica, and the only four-season time series of weekly Fourier transform infrared (FTIR) measurements of organic functional groups in Antarctica. This paper characterizes the sources of organic aerosol across four seasons in Antarctica. Dust, sea salt, and non-sea salt sulfate mass concentrations measured by X-ray fluorescence (XRF) are used to separate the seasonal contributions to inorganic particle components. Seasonal patterns of natural marine and coastal-sourced organic aerosol are identified from the functional groups after separation of local emissions.

\section{Methods}

The AWARE aerosol measurements were collected from 23 November 2015 to 29 December 2016 at the Cosray site on the eastern edge of McMurdo Station $\left(77.85^{\circ} \mathrm{S}\right.$, $166.66^{\circ} \mathrm{E}$ ), which is located on the southern tip of Ross Island in Antarctica. To quantify seasonal differences, four seasons were defined as summer (November through February), fall (March through April), winter (May through August), and spring (September through October) (Fig. 1). The 4-month winter is characterized by irradiance of nearly zero and average temperature below $-20^{\circ} \mathrm{C}$. The 4-month summer had irradiance above $250 \mathrm{~W} \mathrm{~m}^{-2}$ and temperature higher than $-10^{\circ} \mathrm{C}$. Spring and fall marked transitions between summer and winter. The station hosts more than 1000 scientists and support personnel during austral summer and consumes more than 2 million gallons of AN-8 diesel fuel (with a $0.3 \%$ sulfur content by weight) for station operations (Mazzera et al., 2001a). The aerosol inlet samples at $\sim 10 \mathrm{~m}$ above ground level and has a rain guard and bug screen; $1000 \mathrm{~L} \mathrm{~min}^{-1}$ turbulent flow through $4.6 \mathrm{~m}$ of large-diameter $(20 \mathrm{~cm} \mathrm{ID})$, powder-coated aluminum tubing; a $2.1 \mathrm{~m}$ smaller-diameter tube $(4.76 \mathrm{~cm} \mathrm{ID})$ that extracts $150 \mathrm{~L} \mathrm{~min}^{-1}$ flow from the center of the largerdiameter tubing; and a flow distributor with five ports, each drawing $30 \mathrm{~L} \mathrm{~min}^{-1}$ through $25 \mathrm{~cm}$ of $1.59 \mathrm{~cm}\left(5 / 8^{\prime \prime}\right)$ inner diameter stainless-steel tubing. The size-dependent losses were measured below $10 \%$ for particles from $10 \mathrm{~nm}$ to $10 \mu \mathrm{m}$ diameter (https://www.arm.gov/publications/tech reports/doe-sc-arm-tr-191.pdf, last access: 11 June 2018). Other details of the measurement system can be found online in the description of the second ARM Mobile Facility (AMF2, https://www.arm.gov/capabilities/observatories/ amf, last access: 11 June 2018) and Aerosol Observing System (AOS, https://www.arm.gov/capabilities/instruments/ aos, last access: 11 June 2018).

Ambient aerosol particles were measured by CPC (Condensation Particle Counter, TSI model 3772), HTDMA (Hygroscopic Tandem Differential Mobility Analyser, Brechtel model 3002), and CCN Counter (Cloud Condensation Nuclei, DMT model CCN100) and were collected on filters for off-line FTIR and X-ray fluorescence. CN (condensation nuclei from CPC) concentrations had frequent short-lived increases that typically had high concentrations ( $>1000$ particles $\mathrm{cm}^{-3}$ for $1 \mathrm{~Hz} \mathrm{CN}$ ), which we attributed to short-term local contamination events (SLCEs) (Fig. S1 in the Supplement). High CN concentrations $\left(>1000 \mathrm{~cm}^{-3}\right)$ occurred $48 \%$ of the time when the wind was from the west 


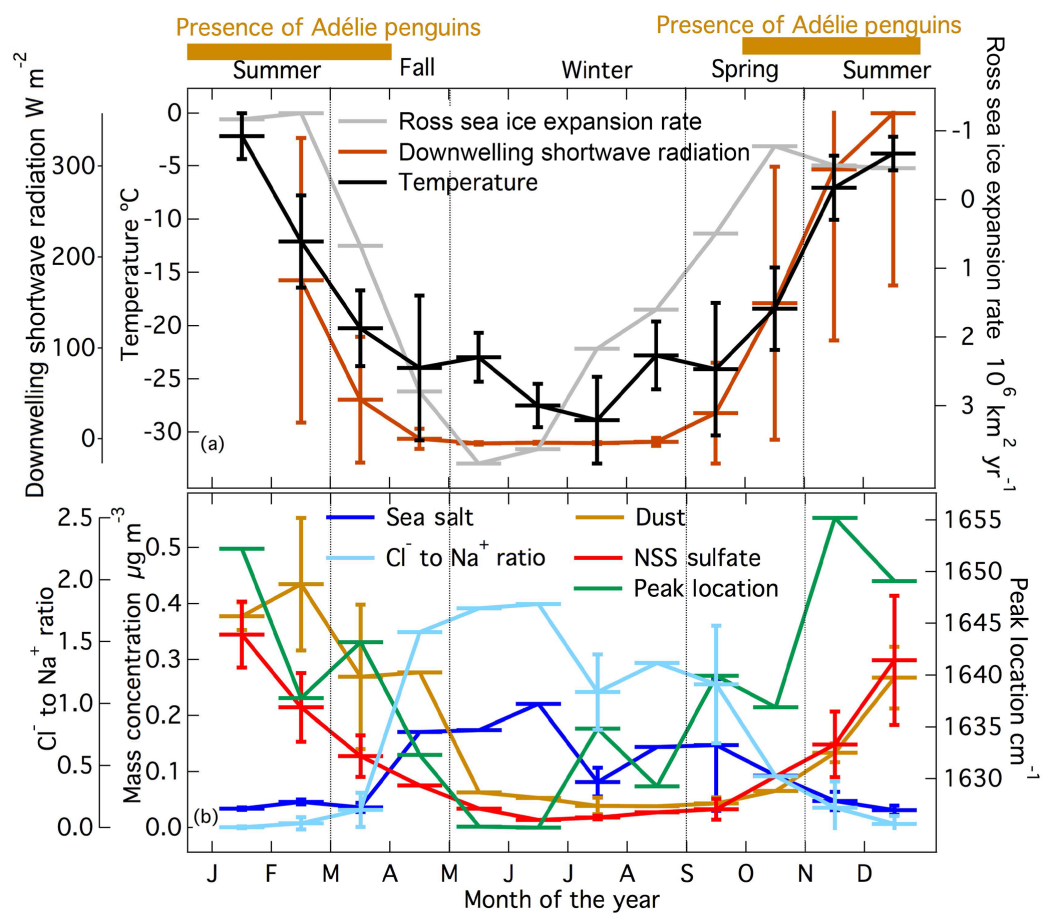

Figure 1. Monthly average of (a) temperature, shortwave downwelling irradiance measured in this study, and sea ice expansion rate of the Ross Sea (Holland, 2014); (b) Sea salt, dust, and non-sea salt sulfate concentration from XRF and FTIR peak location at $1500-1800 \mathrm{~cm}^{-1}$ wavenumber region. Standard deviations are shown on the plot as error bars.

(Fig. S2), which is the same direction as the McMurdo Station central facilities. However, westerly winds only occurred $3 \%$ of the time, so emissions at McMurdo Station were unlikely to account for most of the emissions. Spikes were separated using a "de-spike" algorithm based on running median filters (Beaton and Tukey, 1974; Tukey, 1977; Velleman, 1977; Goring and Nikora, 2002). We applied a running median length of $24 \mathrm{~h}$ and weighted by cosine bell running mean of $24 \mathrm{~h}$ to the $1 \mathrm{~Hz} \mathrm{CN}$ concentration and assigned the $\mathrm{CN}$ concentration above the resulting filter as SLCEs. The SLCEs were characterized by an average duration of less than $1 \mathrm{~h}(0.5 \pm 6 \mathrm{~min})$, rapid rate of concentration change $\left(8520 \pm 36780 \mathrm{~cm}^{-3} \mathrm{~min}^{-1}\right)$, and concentrations exceeding $1000 \mathrm{~cm}^{-3}$. After SLCEs (spikes) were removed, the $24 \mathrm{~h}$ running median concentration was interpreted to be the natural background $\mathrm{CN}$, for reasons discussed in Sect. 3 .

Submicron aerosol particle samples were collected on prescanned Teflon filters (Teflon, Pall Life Science Inc., $37 \mathrm{~mm}$ diameter, $1.0 \mu \mathrm{m}$ pore size) behind a $\mathrm{PM}_{1}$ sharp-cut cyclone (SCC2.229 $\mathrm{PM}_{1}$, BGI Inc.). One sample filter and one background filter were collected each week. Samples were frozen and transported to the UCSD laboratory for FTIR spectroscopy. A Bruker Tensor 27 FTIR spectrometer with a deuterated triglycine sulfate (DTGS) detector (Bruker, Waltham, MA) was used to scan the filters both before and after sampling. An automated algorithm was applied to quantify the mass of the organic functional groups (Takahama et al., 2013; Russell et al., 2009). Four groups (alkane, amine, hydroxyl, and carboxylic acid) were quantified by the area of absorption peaks and the sum of the mass of the five functional groups. Other groups (organonitrate, organosulfate, and nonacid carbonyl) were fit but all samples were below detection limit. The detection limit and error for each functional group is the larger of twice the standard deviation of the absorption values associated with blank filters and the visual determination of the minimum peak size that could be distinguished from spectral noise (Maria et al., 2002). The detection limit of OM was $0.09 \mu \mathrm{g}$ based on the sum of the detection limits of the three largest functional groups during the project (alkane, hydroxyl, and amine). For the weekly air sampling volume of $80 \mathrm{~m}^{3}$ used in this study, this loading corresponds to a concentration of $0.001 \mu \mathrm{g} \mathrm{m}^{-3}$. OM is calculated as the sum of all functional groups measured above detection, based on the assumptions of Russell (2003). Subsequent evaluations and intercomparisons (Takahama et al., 2013; Russell et al., 2009; Maria et al., 2002) have shown that errors associated with functional groups that are not quantified because of Teflon interference and semivolatile properties are accounted for within the stated $\pm 20 \%$ uncertainty for ambient particle compositions. The ammonium mass is not quantified by FTIR of Teflon filter samples because ammonium nitrate is semivolatile. The location of absorption by sulfate in FTIR coincides with the location of Teflon absorption. Since the absorption by the Teflon filter far exceeds that 
of the sulfate particles, sulfate cannot be measured on this substrate. Sulfur was measured by XRF and is expected to be largely ammonium sulfate, since organosulfate and bisulfate were below the limit of quantification. Pure $(>99 \%)$ uric acid (Sigma-Aldrich) and urea (Fisher Scientific) were dissolved in water, atomized, and collected on triplicate Teflon filters to provide FTIR reference spectra for comparison of the amide group region. FTIR spectra were baselined by subtracting a combination of piecewise linear and polynomial regressions from the spectrum using an automated algorithm (Takahama et al., 2013).

Positive matrix factorization (PMF) was applied to the baselined FTIR spectra for the $\mathrm{PM}_{1}$ samples collected in 2016 at McMurdo Station with PMF2 V4.2 (Paatero and Tapper, 1994; Paatero, 1997). Six-factor solution spaces (1 6) were considered. Fpeak values from -2 to 2 at 0.5 increments were considered. Seeds of 1, 10, and 100 were used at each Fpeak and factor number to examine the robustness of each solution. There was little change in solutions with rotations for all solutions. $Q / Q_{\text {expected }}$ decreases as factor number increases for all solutions (Table S2). The two-factor solution is considered robust because the spectra are almost identical for all rotations and seeding conditions (Fig. S3). The solution leaves an average of $23 \%$ of the OM as residual. The two factors are not correlated in time and do not have similar spectra (Table S2). The new factor identified from the three-factor solutions is either degenerate or very similar (cosine similarity $=0.99$ ) to one of the first two factors. Similarly for four or more factor solutions two or more degenerate or duplicate factors are found. This makes the two-factor solution with Fpeak of 0 optimal for the AWARE data set. The small number of factors identified compared to other regions (Russell et al., 2011) is the result of both the low aerosol concentrations and limited personnel access at AWARE, which reduced the time resolution of FTIR samples to 1 week each and yielded only 54 samples in 1 year. The low variability during the study also meant that PMF was unable to separate more than two factors.

In addition, $k$-mean clustering (Hartigan and Wong, 1979) was applied to the baselined FTIR spectra (Takahama et al., 2013). Solutions with 1 to 10 clusters were evaluated. The two-cluster solution was chosen because solutions with three or more clusters included at least one pair of clusters with centroids with cosine similarity higher than 0.95 (Table S2), making those clusters effectively overlapping. The two clusters and two PMF factors were identified as being associated with fossil fuel combustion (FFC) and marine and seabird (M\&S) sources, as described below. Factorization techniques like PMF are applied to separate each individual composition measurement into the independent factors that contribute to its composition, where these factors may represent different sources as well as different formation processes. On the other hand, clustering algorithms are used to sort similar measurements into categories, each of which may contain a mixture of different sources and formation processes and is charac- terized by the centroid to which all measurements in that category are most similar. The similarity of the $k$-mean centroids and PMF factors (cosine similarity $>0.97$ ) indicates that both separations are robust. Since the PMF residual is the fraction of OM that could not be assigned to either factor, the ratio of the residual to the factor OM provides a measure of the uncertainty of the PMF separation - namely the fraction of $\mathrm{OM}$ that could be missing from the factor. The ratio of the PMF residual to the FFC OM varies from $29 \%$ in winter to $63 \%$ in summer, making this result more likely to represent all of the FFC OM in winter when FFC OM is a larger relative fraction of OM. Similarly, the PMF residual is $33 \%$ of M\&S OM in summer, indicating the source separation could be missing a third of M\&S OM. In contrast, the PMF residual is 9 times larger than the M\&S OM in winter (Table 1), making the quantification of M\&S OM in winter very uncertain.

Half of the filters (25) were selected for XRF (Chester Labnet, OR) quantification of major elements above $23 \mathrm{amu}$. The elements $\mathrm{Na}, \mathrm{Mg}, \mathrm{Al}, \mathrm{Si}, \mathrm{P}, \mathrm{S}, \mathrm{Cl}, \mathrm{K}, \mathrm{Ca}, \mathrm{Ti}, \mathrm{V}, \mathrm{Cr}, \mathrm{Mn}$, $\mathrm{Fe}, \mathrm{Co}, \mathrm{Ni}, \mathrm{Cu}, \mathrm{Zn}, \mathrm{Br}, \mathrm{Rb}, \mathrm{Sr}, \mathrm{Zr}, \mathrm{Ag}, \mathrm{Pb}$, and Ba had mass above the detection limit (3 times the uncertainty) for $95 \%$ of the samples and are used here. The mass of dust was calculated from XRF metal concentrations, assuming dust consists of $\mathrm{MgCO}_{3}, \mathrm{Al}_{2} \mathrm{O}_{3}, \mathrm{SiO}_{2}, \mathrm{~K}_{2} \mathrm{O}, \mathrm{CaCO}_{3}, \mathrm{TiO}_{2}, \mathrm{Fe}_{2} \mathrm{O}_{3}, \mathrm{MnO}$, and $\mathrm{BaO}$ (Usher et al., 2003) after excluding mass associated with sea salt. Sea salt particle mass components were calculated from XRF-measured $\mathrm{Na}$ and $\mathrm{Cl}$ concentration (Frossard et al., 2014b; Modini et al., 2015).

The CPC measured particles with diameters larger than $10 \mathrm{~nm}$ and operated continuously, except from 29 March to 7 April 2016 when a malfunction occurred (Fig. S1). The CCN Counter measured the particle concentration activated at supersaturations of $0.1,0.2,0.5,0.8$, and $1.0 \%$ during AWARE, with only short time periods of missing data (Fig. S1). HTDMA provided humidified aerosol size distributions for five dry particle sizes at specified relative humidity $(\mathrm{RH}=90 \%)$ for two periods during the campaign: 23 November to 20 December 2015 and 16 to 31 January 2016. Aerosol particle growth factors $\left(\mathrm{GF}_{i}\right)$ from the HTDMA measurements were calculated as the ratio of humidified particle diameter of size $i$ to the selected dry diameter. Mean growth factors (GFs) and hygroscopicity parameters $(\kappa)$ (Petters and Kreidenweis, 2007; Su et al., 2010) were calculated from Eqs. (1) and (2):

$$
\begin{gathered}
\overline{\mathrm{GF}}=\frac{\sum_{i} \mathrm{GF}_{i}\left(\frac{\mathrm{d} N}{\mathrm{~d} \log D_{p}}\right)_{i}}{\sum_{i}\left(\frac{\mathrm{d} N}{\mathrm{~d} \log D_{p}}\right)_{i}}, \\
\kappa=\frac{\left(\overline{\mathrm{GF}}^{3}-1\right)\left(1-a_{\mathrm{w}}\right)}{a_{\mathrm{w}}},
\end{gathered}
$$

where $N$ is the measured number concentration and $a_{\mathrm{w}}$ is water activity (Rickards et al., 2013). 
Table 1. Mean concentrations and ratios with standard deviations during 2016 at McMurdo.

\begin{tabular}{|c|c|c|c|c|c|}
\hline \multicolumn{2}{|l|}{ Season } & \multirow{2}{*}{$\begin{array}{r}\text { Spring } \\
11.2 \pm 13.3\end{array}$} & \multirow{2}{*}{$\begin{array}{r}\text { Summer } \\
40.1 \pm 34.2\end{array}$} & \multirow{2}{*}{$\begin{array}{r}\text { Fall } \\
9.7 \pm 6.6\end{array}$} & \multirow{2}{*}{$\begin{array}{r}\text { Winter } \\
7.1 \pm 8.5\end{array}$} \\
\hline CCN Number & $0.1 \% \mathrm{SS}$ & & & & \\
\hline Concentration $\left(\mathrm{cm}^{-3}\right)$ & & $(0.07 \pm 0.06)$ & $(0.08 \pm 0.06)$ & $(0.06 \pm 0.05)$ & $(0.1 \pm 0.09)$ \\
\hline \multirow[t]{8}{*}{ (CCN / SLCE-removed CN) } & $0.2 \% \mathrm{SS}$ & $37.9 \pm 36.4$ & $131 \pm 80.2$ & $48.2 \pm 29.3$ & $18.6 \pm 20.5$ \\
\hline & & $(0.19 \pm 0.11)$ & $(0.26 \pm 0.12)$ & $(0.29 \pm 0.11)$ & $(0.26 \pm 0.14)$ \\
\hline & $0.5 \% \mathrm{SS}$ & $72.1 \pm 48.5$ & $276.4 \pm 147.9$ & $104 \pm 60.7$ & $33.3 \pm 25.3$ \\
\hline & & $(0.37 \pm 0.20)$ & $(0.56 \pm 0.24)$ & $(0.63 \pm 0.20)$ & $(0.49 \pm 0.26)$ \\
\hline & $0.8 \% \mathrm{SS}$ & $99.7 \pm 73.9$ & $348 \pm 203$ & $124 \pm 72.3$ & $42.9 \pm 39.6$ \\
\hline & & $(0.5 \pm 0.23)$ & $(0.68 \pm 0.25)$ & $(0.75 \pm 0.23)$ & $(0.57 \pm 0.29)$ \\
\hline & $1 \% \mathrm{SS}$ & $117 \pm 110$ & $371 \pm 234$ & $132 \pm 77.5$ & $48.5 \pm 50.2$ \\
\hline & & $(0.55 \pm 0.24)$ & $(0.73 \pm 0.26)$ & $(0.8 \pm 0.23)$ & $(0.6 \pm 0.30)$ \\
\hline \multirow[t]{2}{*}{$\mathrm{CN}\left(\mathrm{cm}^{-3}\right)$} & CN SLCE-removed & $161 \pm 94$ & $400 \pm 228$ & $141 \pm 88$ & $65 \pm 77$ \\
\hline & $\mathrm{CN}$ & $376 \pm 571$ & $740 \pm 693$ & $241 \pm 187$ & $237 \pm 502$ \\
\hline Absorption $\left(\mathrm{mM}^{-1}\right)$ & & $0.2 \pm 0.47$ & $0.34 \pm 0.66$ & $0.16 \pm 0.66$ & $0.2 \pm 0.50$ \\
\hline $\begin{array}{l}\text { Measured FTIR OM } \\
\left(\mu \mathrm{g} \mathrm{m}^{-3}\right)\end{array}$ & & $0.06 \pm 0.04$ & $0.27 \pm 0.16$ & $0.07 \pm 0.06$ & $0.04 \pm 0.02$ \\
\hline \multirow[t]{4}{*}{ PMF of FTIR OM } & $\begin{array}{l}\text { FFC OM } \\
\left(\mu \mathrm{g} \mathrm{m}^{-3}\right)\end{array}$ & $0.03 \pm 0.01$ & $0.06 \pm 0.05$ & $0.03 \pm 0.02$ & $0.03 \pm 0.02$ \\
\hline & $\begin{array}{l}\mathrm{M} \& \mathrm{~S} O M \\
\left(\mu \mathrm{g} \mathrm{m}^{-3}\right)\end{array}$ & $0.018 \pm 0.028$ & $0.155 \pm 0.121$ & $0.026 \pm 0.046$ & $0.001 \pm 0.001$ \\
\hline & Residual / FFC & $0.40 \pm 0.72$ & $0.63 \pm 0.84$ & $0.36 \pm 0.49$ & $0.28 \pm 0.52$ \\
\hline & Residual / M\&S & $1.12 \pm 097$ & $0.33 \pm 0.46$ & $1.03 \pm 0.63$ & $9.22 \pm 7.74$ \\
\hline
\end{tabular}

Meteorological variables (temperature, humidity, wind speed, and wind direction) were measured with a Vaisala model WXT-520 (Helsinki, Finland). The Surface Energy Balance System (SEBS) included upwelling and downwelling solar and infrared radiometers at the measurement site at McMurdo Station from 4 February to 29 December 2016. Aerosol absorption was measured at three wavelengths $(470,522$ and $660 \mathrm{~nm})$ by a Particle Soot Absorption Photometer (PSAP; Radiance Research, Seattle, WA). The PSAP absorption at $660 \mathrm{~nm}$ was used as a proxy for black carbon (BC) because it is expected to have the least interference from brown carbon (Olson et al., 2015).

\section{$3 \mathrm{CN}, \mathrm{CCN}$, hygroscopicity, and inorganic particle measurements}

$19 \%$ of the $1 \mathrm{~Hz} \mathrm{CN}$ measurements recorded during the project were identified as SLCEs, and the average of the concentrations for those times contributed $55 \%$ of the projectaverage CN concentrations. The distribution of SLCE duration and timing (Fig. S4) shows that SLCEs were approximately 2 times more frequent during local daytime than nighttime. This short duration and largely daytime timing of SLCEs suggests that site maintenance and nearby road traffic are likely responsible for many of the high $\mathrm{CN}$ events.

There are two reasons why the $\mathrm{CN}$ concentrations that remain after SLCEs (spikes) are removed are considered representative of the natural background rather than local pol- lution from McMurdo Station activities: First, the SLCE CN concentration is correlated weakly to $\mathrm{BC}(r=0.48)$, but the background $\mathrm{CN}$ is correlated negatively to $\mathrm{BC}$ absorption $(r=-0.4)$. Second, the two indicators of combustion-related pollution (BC absorption and the FFC factor) were approximately 2 times higher in summer than winter (Table 1), which is similar to the 2-fold increase in SLCE CN in summer compared to winter but not enough to account for the 7-fold increase in the background (SLCE-removed) $\mathrm{CN}$ in summer compared to winter. Consequently, this larger summertime difference in background $\mathrm{CN}$ is likely associated with the higher productivity of natural sources in summer. More specifically, the $\mathrm{CN}$ concentration associated with natural sources was very low $\left(\sim 60 \mathrm{~cm}^{-3}\right)$ in winter during low phytoplankton activity but as high as $2000 \mathrm{~cm}^{-3}$ in summer (Fig. S1), indicating a significant increase in biogenic (sulfate or organic) $\mathrm{CN}$.

SLCEs had nearly no contribution to $\mathrm{CCN}$, which is consistent with SLCE particles having extremely low hygroscopicity and being freshly emitted from fuel combustion (Wex et al., 2010) (Fig. S1). The CCN measurements did not have short-term spikes even at the highest supersaturation level $(1 \%)$, at which only $0.1 \%$ of the measurements were $5 \%$ higher than the background $\mathrm{CN}$. The absence of the SLCE in the CCN measurements is likely the result of the local pollution having hygroscopicity both too small and too low to serve as $\mathrm{CCN}$ at $1 \%$ or below. The $\mathrm{CCN}$ concentration correlated moderately or strongly to background $\mathrm{CN}$ 
$(r=0.80,0.83,0.87$, and 0.88 for $0.2,0.5,0.8$, and $1 \% \mathrm{SS}$, respectively). $\mathrm{CCN}$ and $\mathrm{CN}$ were 5 to 7 times higher during summer, but the ratio of $\mathrm{CCN} / \mathrm{CN}$ changed less than $30 \%$ throughout the year (Table 1). CCN / CN was largely constant at all five supersaturations during most of 2016, but from late September to early October the ratio of $\mathrm{CCN} / \mathrm{CN}$ decreased to 0.5 at $1 \%$ supersaturation (Fig. S1). This decrease of the ratio of $\mathrm{CCN}$ to background (spike-removed) $\mathrm{CN}$ during the winter-spring transition could be caused by changes in particle size and composition. One such cause would be additional $\mathrm{CN}$ that are too small to contribute to CCN. Previous observations at a site $10 \mathrm{~km}$ from McMurdo Station showed an increase in the fraction of $\mathrm{CN}$ smaller than $250 \mathrm{~nm}$ at polar sunrise (September-October), although a specific cause was not clear (Giordano et al., 2017). The higher $\mathrm{CCN} / \mathrm{CN}$ ratio in the summer (Table 1) is consistent with both the higher biogenic sulfate contributions during the highest productivity season (summer) and the slightly larger diameter of the accumulation mode particles observed in previous summers (Kim et al., 2017).

The growth factors and hygroscopicity parameters were both nearly constant during the two measurement periods (Fig. S5), with values of $1.5 \pm 0.3$ for growth factors and $0.4 \pm 0.1$ for hygroscopicity parameters. These numbers were constant across the measured size range of 50 to $250 \mathrm{~nm}$ diameter and are comparable to other observations in the Antarctic region (Wex et al., 2010; Asmi et al., 2010; Kim et al., 2017). The particles that had hygroscopicity too low to grow measurably may be those that were emitted by local anthropogenic emissions. The moderate correlation of $\mathrm{BC}$ absorption to the fraction of particles that did not grow at increased relative humidity in the HTDMA ( $R=0.52$, Fig. 2 a) indicates that the $\mathrm{BC}$-containing particles could be the particles that have low hygroscopicity. In addition, BC absorption correlated moderately to the nonactivated $\mathrm{CN}$ particles (1-CCN / CN) $(R=0.34$ for $1 \%$ supersaturation, Fig. $2 \mathrm{~b})$. Since BC-containing particles, such as those freshly emitted from combustion sources, have been shown to have low hygroscopicity (Peng et al., 2017; Vu et al., 2017), these correlations are consistent with the particles that did not take up water being those that were emitted by local combustion activities.

XRF measurements of elemental concentrations of $\mathrm{S}, \mathrm{P}$, $\mathrm{K}, \mathrm{Ca}, \mathrm{Si}, \mathrm{Mn}, \mathrm{Al}, \mathrm{Ag}, \mathrm{Fe}$, and $\mathrm{V}$ were 2 to 15 times higher in summer than in winter (Fig. S6). Submicron dust mass concentration was 7 times higher in summer, consistent with the lack of exposed soil in winter (Fig. 1). Sea salt particle mass concentration (Fig. 1) was 3 times higher in winter than in summer, consistent with the higher circumpolar wind speed providing more sea spray in winter than summer (Bintanja et al., 2014). The measured $\mathrm{Cl}^{-} / \mathrm{Na}^{+}$of 2 represents a large sodium deficiency in wintertime submicron particles (Fig. 1). The depletion of $\mathrm{Na}^{+}$relative to $\mathrm{Cl}^{-}$in winter indicates a likely contribution to the aerosol submicron mass from wind-blown frost flowers (Alvarez-Aviles et

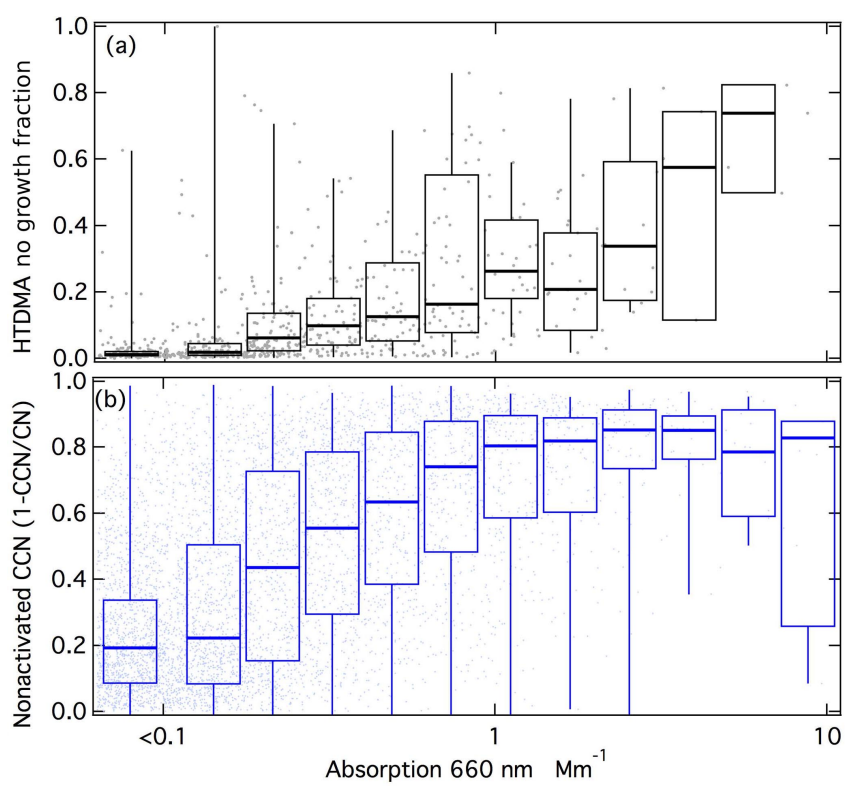

Figure 2. Scatter and box-whisker plot of PSAP $660 \mathrm{~nm}$ absorption and (a) HTDMA no growth fraction $(r=0.52)$; (b) nonactivated $\mathrm{CCN}$ fraction (1-CCN / SLCE-removed CN) for $1 \%$ supersaturation $(r=0.34)$. The boxes show the 25 th, 50 th, and 75 th percentile values; the whiskers show the minimum and maximum values.

al., 2008; Thomas and Dieckmann, 2003; Shaw et al., 2010). This sodium depletion is the result of $\mathrm{Na}_{2} \mathrm{SO}_{4}$ precipitating out from sea ice brine before frost flowers wick up the remaining salt solution. Blowing snow could also contribute to submicron particles (Domine et al., 2004), but this source has not been associated with a substantial sodium deficiency in submicron particle composition (Gordon and Taylor, 2009).

If either frost flowers or blowing snow were generated near the site, we would expect a correlation of concentrations to wind speed at higher wind speeds, since both sources have been characterized as requiring wind speed thresholds of approximately $7 \mathrm{~m} \mathrm{~s}^{-1}$ for lofting of particles (Schmidt, 1981; Shaw et al., 2010). During AWARE, 1 min wind speed only exceeded this threshold by $1 \mathrm{~m} \mathrm{~s}^{-1}$ for $24 \%$ of the time, and the weekly average wind speed was never higher than $7 \mathrm{~m} \mathrm{~s}^{-1}$. Wind speed had no correlation to CN concentration for the campaign $(r=-0.32)$ or for winter $(r=-0.31)$. In addition, there was no correlation $(R=-0.15)$ of submicron $\mathrm{CN}$ number with wind speed $\left(>8 \mathrm{~m} \mathrm{~s}^{-1}\right)$, as would be expected for blowing snow generated locally (Yang et al., 2008). The M\&S factor concentration also showed no correlation $(r=0.1)$ to the fraction of time with high wind speed $\left(>8 \mathrm{~m} \mathrm{~s}^{-1}\right)$. While these relationships do not support the attribution of the wintertime salt mass to either frost flowers or blowing snow, they do not rule it out since the particles may have been lofted upwind and transported to McMurdo Station. A recent model simulation (Huang and Jaegle, 2017) predicted that blowing snow has significantly higher contributions to submicron particle mass than frost flowers in 


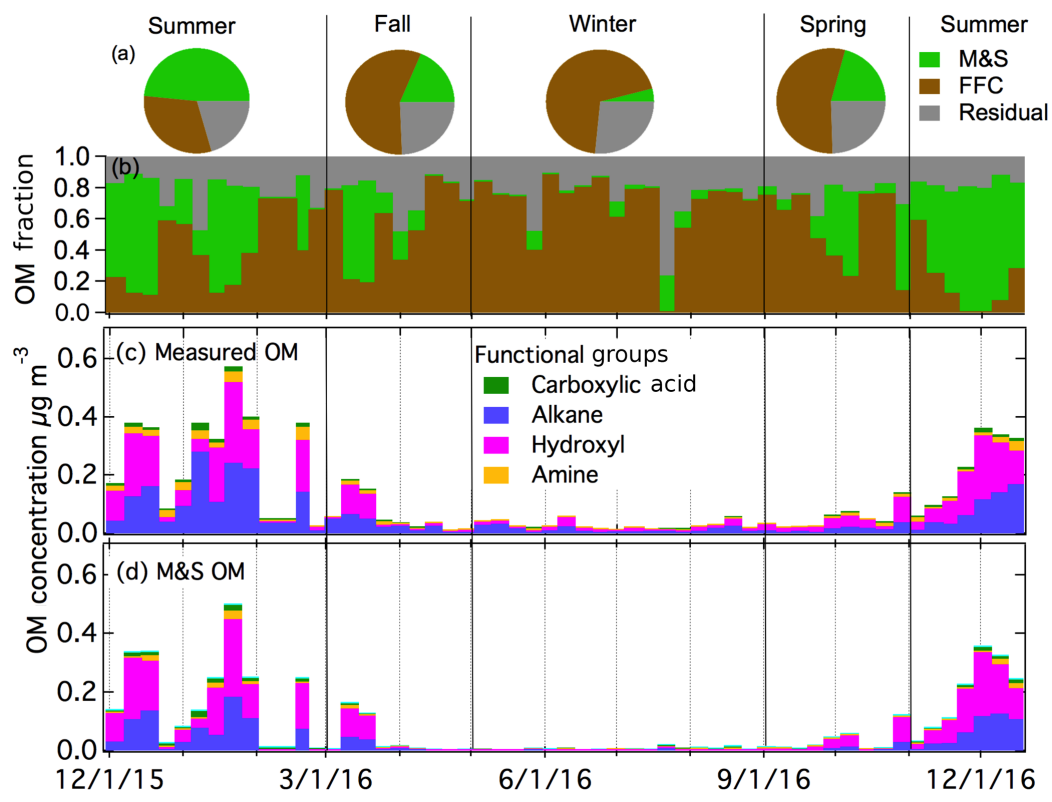

Figure 3. (a) Mass fraction of PMF factors in four seasons. Time series of (b) PMF factor OM fractions, (c) OM concentration with functional groups, and (d) M\&S OM concentration with functional groups.

Antarctica and the Arctic, but also showed that the region at the north edge of the Ross Ice Shelf (including Ross Island) had both higher emissions $\left(>0.6 \times 10^{-6} \mathrm{~kg} \mathrm{~m}^{-2} \mathrm{~d}^{-1}\right)$ and concentration $\left(>1.5 \mu \mathrm{g} \mathrm{m}^{-3}\right)$ from frost flowers than the emissions $\left(<0.4 \times 10^{-6} \mathrm{~kg} \mathrm{~m}^{-2} \mathrm{~d}^{-1}\right)$ and concentration $\left(<1.0 \mu \mathrm{g} \mathrm{m}^{-3}\right)$ from blowing snow, consistent with the finding that wintertime $\mathrm{OM}$ at McMurdo Station were more likely from frost flowers than blowing snow.

\section{Organic mass and composition}

The measured organic functional group mass concentrations are shown in Fig. 3c. The average OM is $0.13 \mu \mathrm{g} \mathrm{m}^{-3}$ for AWARE, with hydroxyl groups having the highest mass fraction $(41 \%)$, followed by alkane (39\%), amine $(13 \%)$, and carboxylic acid $(7 \%)$ groups. Similar to $\mathrm{CN}$ concentrations, OM was highest in summer $\left(0.27 \mu \mathrm{g} \mathrm{m}^{-3}\right)$ and lowest in winter $\left(0.04 \mu \mathrm{g} \mathrm{m}^{-3}\right)$. Arctic OM at Utqiagivik (formerly Barrow) and Alert showed a very different seasonal pattern, with low concentrations in Arctic summer $\left(0.03\right.$ and $<0.5 \mu \mathrm{g} \mathrm{m}^{-3}$ in Alert and Utqiagivik, respectively) and high concentrations in winter and spring $\left(0.3\right.$ and $1 \mu \mathrm{g} \mathrm{m}^{-3}$ in Alert and Utqiagivik, respectively) (Frossard et al., 2011; Leaitch et al., 2018). Consistent with OM, CN concentrations at these two Arctic sites, with particle size range of $80-500 \mathrm{~nm}$ at Alert and $>100 \mathrm{~nm}$ at Utqiagvik, were also low in Arctic summer $\left(<50\right.$ and $100-300 \mathrm{~cm}^{-3}$ at Alert and Utqiagivik, respectively) and high in winter and spring (>100 and 400$1000 \mathrm{~cm}^{-3}$ at Alert and Utqiagivik, respectively) (Croft et al., 2016a; Polissar et al., 1999). The springtime high concentrations in the Arctic result from long-range transport from midlatitudes after the breakup of the vortex. The lack of substantial pollution sources at southern midlatitudes (compared to those at northern midlatitudes) means the Antarctic does not have an equivalent haze in spring (Stohl, 2006; Stohl and Sodemann, 2010; Russell and Shaw, 2015). The higher summer OM in Antarctica is likely produced by the specific local conditions of the three polar sites, namely that Ross Island has higher marine and seabird activity compared to Utqiagivik and Alert.

The FFC cluster and factor are similar to each other (cosine similarity $=0.97$ ) and are both named because of the similarity of the spectra to factors identified as FFC previously (Price et al., 2017; Guzman-Morales et al., 2014; Saliba et al., 2017). The FFC factor has two narrow peaks at 2865 and $2934 \mathrm{~cm}^{-1}$ that are characteristic of long-chain hydrocarbons and a cosine similarity greater than 0.8 with factor spectra identified previously as urban combustion emissions (Guzman-Morales et al., 2014) and fresh ship engine emissions (Price et al., 2017). The FFC factor has alkane and amine groups that account for $80 \%$ OM (Fig. 4), which is consistent with urban combustion emissions and vehicle engine tests (Guzman-Morales et al., 2014; Saliba et al., 2017). The FFC factor was $73 \%$ OM in winter but only $23 \%$ in summer (Fig. 3a and b). The FFC factor concentration is weakly or moderately correlated to $\mathrm{Ca}, \mathrm{P}, \mathrm{Fe}, \mathrm{Cu}, \mathrm{Cr}, \mathrm{Mn}$, and $\mathrm{Zn}(r=0.3-0.5)$, which have been identified as tracers of vehicle emissions (Lin et al., 2015; Cheung et al., 2010).

The primary amine peak $\left(1620 \mathrm{~cm}^{-1}\right)$ is present in both FFC and M\&S factors at McMurdo Station (Fig. 5), consistent with previous studies (Shaw et al., 2010; GuzmanMorales et al., 2014; Price et al., 2017; Leaitch et al., 2018). 


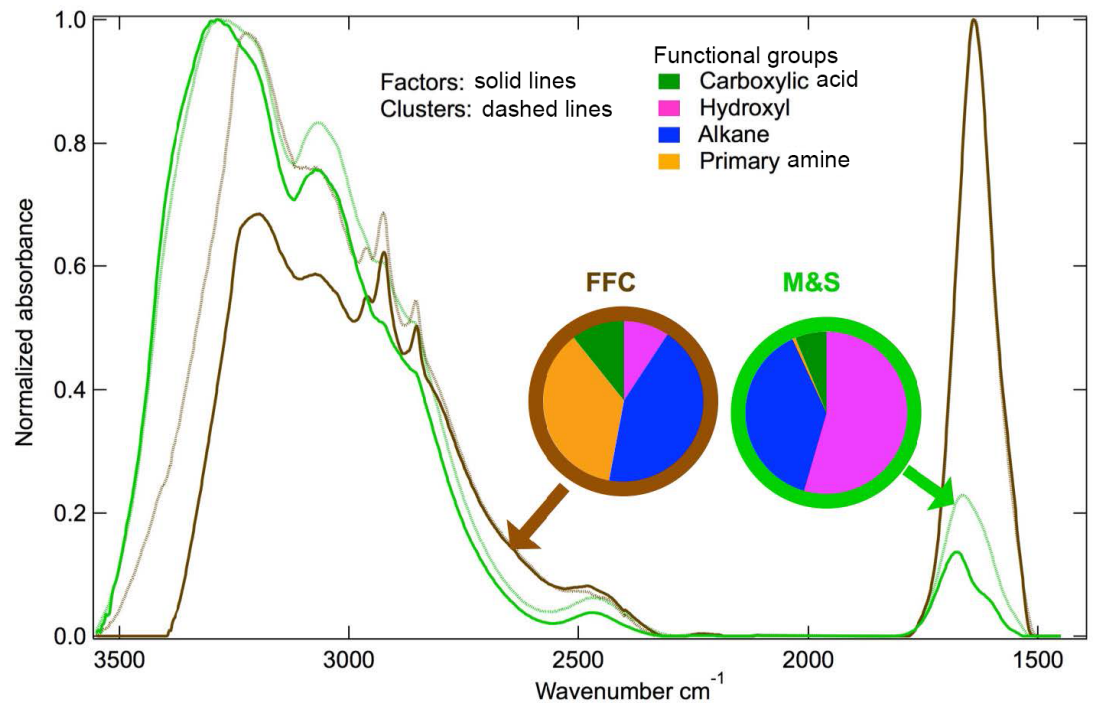

Figure 4. Normalized spectra from $k$-mean clustering centroids and PMF factors. Functional group fractions of PMF factors are shown in the pie charts.

The difference between the FFC and M\&S spectra is that FFC has double sharp alkane group peaks at $3000 \mathrm{~cm}^{-1}$ but M\&S has a broad hydroxyl group absorption at $3400 \mathrm{~cm}^{-1}$ (Fig. 4). Ammonium has peaks at 3050 and $3200 \mathrm{~cm}^{-1}$ and contributes to both FFC and M\&S spectra (Fig. 4).

The M\&S factor is identified as "marine" because of its high hydroxyl group fraction, which is similar to past marine sea spray factors (Russell et al., 2010), and as "seabird" because of absorption from ammonium and an organic nitrogen peak that is likely associated with coastal penguin emissions. The high hydroxyl group that accounted for $55 \% \mathrm{OM}$ in the M\&S factor makes this factor overall similar to the marine factors identified in measurements at Utqiagivik and Alert (cosine similarity $=0.53-0.57$ ) (Shaw et al., 2010; Leaitch et al., 2018) (Figs. 3 and 4). The M\&S hydroxyl group fraction is lower than the Arctic marine factors that have $80 \%$ hydroxyl (Shaw et al., 2010; Leaitch et al., 2018).

Utqiagivik and Alert had higher marine OM concentrations in winter than in summer. Likely this is because these two Arctic sites did not have the large seabird contributions that contributed to the M\&S factor on Ross Island during summer (Lyver et al., 2014). The smaller seabird populations near the Arctic sites also meant that Utqiagivik and Alert OM had only very small amide contributions (Fig. 5). The M\&S factor has higher alkane $(38 \%)$ and amine $(8 \%)$ group mass compared to two marine factors in Arctic regions that had only $6 \%$ alkane and $6 \%$ amine group mass (Shaw et al., 2010; Leaitch et al., 2018). This factor contributed a substantial fraction of organic mass in summer $(58 \%)$ but very little in winter (5\%) (Fig. 3b). The M\&S organic mass concentration was only $0.001 \mu \mathrm{g} \mathrm{m}{ }^{-3}$ during winter and was $0.15 \mu \mathrm{g} \mathrm{m}^{-3}$ during summer (Fig. 3d). The low winter and high summer M\&S OM means that salt was not correlated to the M\&S Factor or- ganic mass, indicating the high summertime concentrations of natural $\mathrm{OM}$ could not be explained by primary marine aerosol contributions alone. Marine OM contributions could be high in winter relative to summer because of the higher regional wind speeds, but their absolute concentration was too low to separate and identify in this set of 541 -week samples. Specifically, the small number of long-duration samples resulted in PMF residuals that were more than 9 times higher than the $M \& S$ factor in winter, so that the marine fraction in winter is very uncertain.

The FTIR spectra for summer samples show an absorption peak at $1680 \mathrm{~cm}^{-1}$ that is not present in winter (Fig. 1). The M\&S factor FTIR absorption peak (Fig. 5) was located at a wavenumber that was both too high $\left(>1630 \mathrm{~cm}^{-1}\right)$ to be primary amine bending and too low $\left(<1714 \mathrm{~cm}^{-1}\right)$ to be carbonyl bending (Fig. 5) (Takahama et al., 2013). Seabirds excrete urea that degrades to uric acid, and the amide groups found in both urea and uric acid could explain the $1680 \mathrm{~cm}^{-1}$ peak in the summer FTIR spectra (Fig. 5). The ammonium peaks (Fig. 4) associated with the M\&S factor are also consistent with ammonia emissions from guano (Legrand et al., 1998), which is taken up on particles as ammonium.

More than 155000 breeding pairs reside in the ice-free areas on Ross Island (Attwood et al., 2014) from October to March (Davis et al., 2001). The three penguin habitats on Ross Island are all less than $100 \mathrm{~km}$ from McMurdo Station (Fig. S2) (Lyver et al., 2014). Previous studies have also attributed aerosol emissions and properties to penguin activities, including ammonia-enhanced new particle formation (Weber et al., 1998) and oxalate-enriched particles and organonitrogen-containing fragments from urea breakdown products (Legrand et al., 2012; Schmale et al., 2013). The finding here of amide groups would be consistent both with 


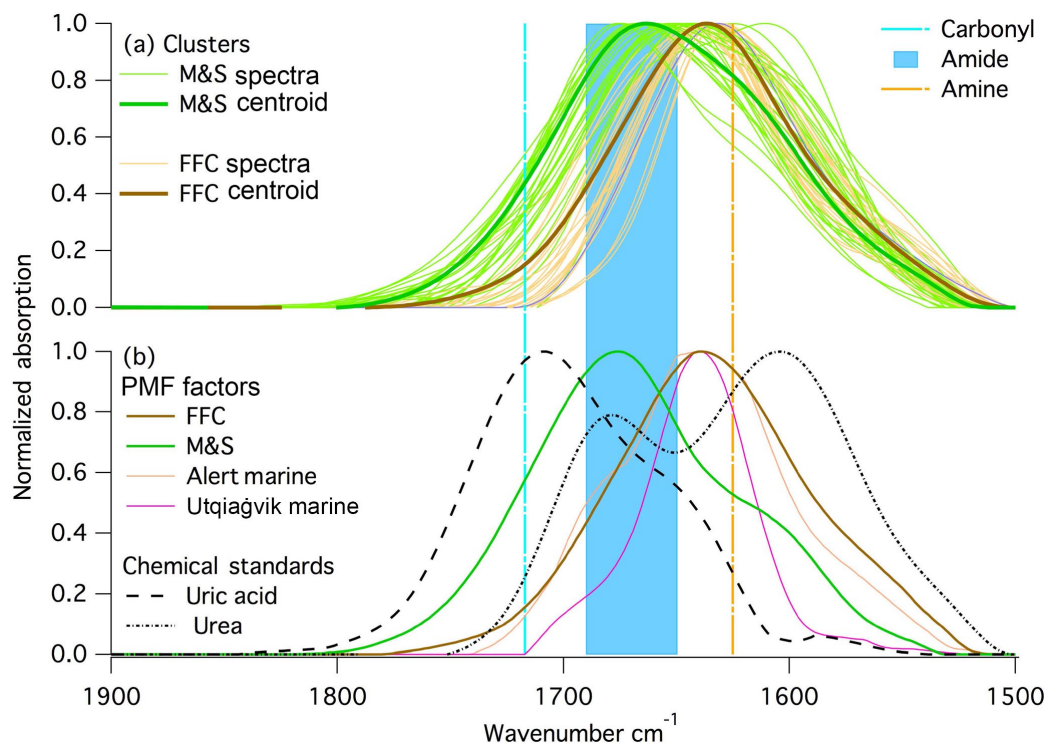

Figure 5. Normalized spectra at 1500 to $1800 \mathrm{~cm}^{-1}$ wavenumber region from (a) $k$-mean clustering centroid and spectra in the clusters; (b) PMF factors from this study and two previous arctic studies, and chemical standards: urea and uric acid. Locations of primary amine and carbonyl group are marked on the figure.

particle formation and with substantial organonitrogen components. Since McMurdo Station is most frequently downwind from Cape Crozier (which is located to the northeast of the sampling site), its estimated $\sim 300000$ penguins are a likely source of this organic and ammonium contribution to particles (Lyver et al., 2014).

This $1680 \mathrm{~cm}^{-1}$ amide peak was present in very small amounts in multiyear Arctic FTIR measurements (Shaw et al., 2010; Leaitch et al., 2018) (Fig. 5), but their low concentrations did not support further investigation. The $1680 \mathrm{~cm}^{-1}$ peak has not been observed in open-ocean marine factors (Russell et al., 2010; Frossard et al., 2014a), suggesting that an open-ocean marine source is not likely. An alternative explanation of the amide group is emissions from seasonal ice microbiota (Dall'Osto et al., 2017). Given the proximity and abundance of seabirds at McMurdo Station, seabirds are the more likely source than sea ice algae or other phytoplankton during AWARE. There are four reasons that the M\&S factor are likely associated with marine and seabird emissions: the $1680 \mathrm{~cm}^{-1}$ signal has been found at two coastal Arctic sites (in small amounts) but not on open-ocean marine studies (Hawkins and Russell, 2010; Leaitch et al., 2018; Shaw et al., 2010; Frossard et al., 2011). This difference suggests that the amide group is likely associated with seabirds, since they are found in coastal marine areas but generally not in open-ocean marine areas. The higher concentrations of the M\&S OM factor coincided with the summer breeding period of a large penguin colony at Cape Crozier, which was upwind during most of the summer. Other possible contributions, such as from algal blooms during ice melting in spring, are not consistent with the northeasterly winds, the amide group, or the seasonality of the M\&S OM. HYSPLIT back trajectories (Draxier and Hess, 1998) did not add useful information because the day-to-day variability exceeded the differences among weekly averages. Weekly-average wind direction was always northeasterly $\left( \pm 45^{\circ}\right)$, so there was insufficient variation to identify sources in different directions. The emissions from seabirds have significant regional implications in polar areas because of their large population and wide distribution (Croft et al., 2016b; Riddick et al., 2012). Chemical transport model simulations suggest that emissions of reduced nitrogen from seabirds in the Arctic could significantly increase aerosol particle formation, and in turn cloud droplet number concentration and cloud albedo, yielding as much as $-0.5 \mathrm{~W} \mathrm{~m}^{-2}$ radiative forcing averaged over the $14000000 \mathrm{~km}^{2}$ of the Arctic Ocean (Croft et al., 2016b).

The measured acid group concentration is likely to be a secondary aerosol contribution since photochemical oxidation has been shown to form highly oxidized molecules including carboxylic acids by photochemical reactions (Xu et al., 2013; Barbaro et al., 2017; Kawamura and Gagosian, 1987; Sax et al., 2005; Charbouillot et al., 2012; Alves and Pio, 2005; Claeys et al., 2007; Alfarra et al., 2006; Stephanou and Stratigakis, 1993). Acids are also present in trace amounts in seawater (Gagosian and Stuermer, 1977; Kawamura and Gagosian, 1987), but the higher concentrations measured here are likely to only be explained by secondary processes. The carboxylic acid group mass concentration that was associated with the $\mathrm{M} \& \mathrm{~S}$ factor was correlated moderately to downwelling shortwave irradiance $(r=0.75$, Fig. 6). 


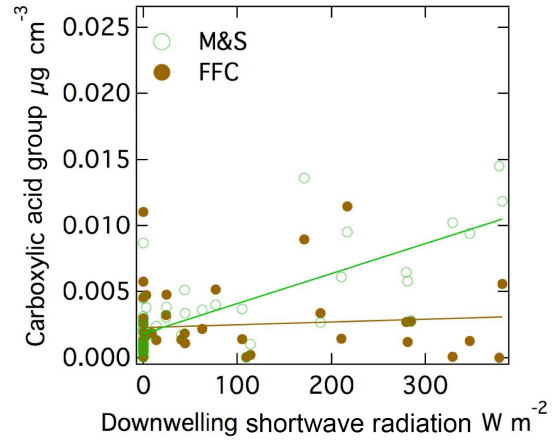

Figure 6. Scatter plot of (a) M\&S carboxylic acid group and shortwave downwelling radiation $(r=0.75)$ and (b) carboxylic acid group in FFC and shortwave downwelling radiation $(r=0.09)$.

Carboxylic acid group mass fractions have also been identified as secondary photochemical products based on their correlation to solar radiation in clean, open-ocean conditions (Frossard et al., 2014a). However, since the seabird emissions were only high in summer when radiation was also generally high, the correlation to radiation does not provide evidence of photochemical contributions in this case. Interestingly, the carboxylic acid group associated with the FFC factor had no correlation $(r=0.09)$ to downwelling shortwave irradiance. This difference may be because the local emissions from McMurdo Station facilities reached the Cosray site in less than $5 \mathrm{~min}$ (since McMurdo Station was $2 \mathrm{~km}$ away and wind speeds were $6 \mathrm{~m} \mathrm{~s}^{-1}$ on average), making them essentially "fresh" primary particles, whereas those from the large upwind penguin colony took $6 \mathrm{~h}$ (since Cape Crozier was $100 \mathrm{~km}$ away and wind speeds were $6 \mathrm{~m} \mathrm{~s}^{-1}$ on average) to reach the site, giving them approximately 50 times more time for photochemical reactions leading to SOA production. It is also possible that the anthropogenic gas-phase precursor emissions had lower SOA acid yields but there is little evidence to support this (Rickard et al., 2010; Wyche et al., 2009; McNeill, 2015). The source of the vaporphase organic precursors of the summer seabird acid groups is not known, but given their substantial contribution to mass is worthy of further investigation.

\section{Conclusions}

The first yearlong organic functional group measurements in Antarctica show the seasonal trend of higher summer concentrations in most of the aerosol measurements. Shortlived contamination events (SLCEs) of typically less than $1 \mathrm{~h}$ (Fig. S1) from local sources were separated from the $\mathrm{CN}$ time series to investigate the more regionally representative or "background" concentrations. With SLCE removed, average $\mathrm{CN}$ concentrations were $65 \mathrm{~cm}^{-3}$ in winter but $400 \mathrm{~cm}^{-3}$ in summer.
The ratio of $\mathrm{CCN}$ to background (spike-removed) $\mathrm{CN}$ was largely constant for most of the measured seasons. Growth factors $(1.5 \pm 0.3)$ and hygroscopicity parameters $\kappa$ $(0.4 \pm 0.1)$ were measured in two 1 -month periods during the 2015-2016 summer and are comparable to marine aerosols reported near Antarctica (Wex et al., 2010; Asmi et al., 2010; Kim et al., 2017).

Both natural dust and biogenic as well as anthropogenic concentrations were more abundant in the summer months due to both the higher sunlight for productivity and the higher site accessibility. The mean summer OM concentration was $0.27 \mu \mathrm{g} \mathrm{m}^{-3}$, which was 7 times higher than winter OM. Hydroxyl and alkane groups were found to be the most abundant and accounted for $80 \%$ of OM. Two factors were identified by PMF with an average residual of $23 \%$ : the M\&S factor was associated with natural marine sea spray and coastal seabird sources, and the FFC was associated with local combustion emissions. The M\&S factor mass concentration was 150 times higher in summer than winter; the FFC factor had a higher concentration than $M \& S$ in winter but the concentrations were so low that the quantification of the $M \& S$ factor in winter is very uncertain.

In addition to the primary amine peak present in past marine sea spray measurements, an FTIR absorption peak at $1680 \mathrm{~cm}^{-1}$ was associated with the $M \& S$ factor in summer. The likely source of this peak as well as the coincident ammonium concentrations was seabird-related emissions from penguin colonies at Cape Crozier. The carboxylic acid group mass in the M\&S factor was high in summer and was likely from secondary products of photochemical reactions.

Data availability. FTIR and XRF measurements are available at UCSD digital archives: https://doi.org/10.6075/J0WM1BKV (Liu et al., 2018). Other data are available on the ARM Data Discovery: https://www.arm.gov/research/campaigns/amf2015aware (last access: 11 June 2018).

Supplement. The supplement related to this article is available online at: https://doi.org/10.5194/acp-18-8571-2018-supplement.

Competing interests. The authors declare that they have no conflict of interest.

Acknowledgements. We would like to thank the ARM (Atmospheric Radiation Measurement) program for the AMF-2 AWARE campaign, which was jointly supported by the National Science Foundation (NSF AWARE grant: DPP-1443549) and Department of Energy (DOE Award number: DE-SC0017981.) We also thank the AWARE personnel, Ryan C. Scott, Colin Jenkinson, Heath H. Powers, Maciej Ryczek, and Gregory Stone, for help collecting samples on site and Savannah Lewis and Gary Cheng for assistance with sample preparation and analysis at Scripps. 
Edited by: Stefania Gilardoni

Reviewed by: three anonymous referees

\section{References}

Alfarra, M. R., Paulsen, D., Gysel, M., Garforth, A. A., Dommen, J., Prévôt, A. S. H., Worsnop, D. R., Baltensperger, U., and Coe, H.: A mass spectrometric study of secondary organic aerosols formed from the photooxidation of anthropogenic and biogenic precursors in a reaction chamber, Atmos. Chem. Phys., 6, 52795293, https://doi.org/10.5194/acp-6-5279-2006, 2006.

Alvarez-Aviles, L., Simpson, W. R., Douglas, T. A., Sturm, M., Perovich, D., and Domine, F.: Frost flower chemical composition during growth and its implications for aerosol production and bromine activation, J. Geophys. Res.-Atmos., 113, D21304, https://doi.org/10.1029/2008jd010277, 2008

Alves, C. A. and Pio, C. A.: Secondary organic compounds in atmospheric aerosols: Speciation and formation mechanisms, J. Brazil. Chem. Soc., 16, 1017-1029, https://doi.org/10.1590/s0103-50532005000600020, 2005.

Arrigo, K. R., van Dijken, G. L., and Bushinsky, S.: Primary production in the Southern Ocean, 1997-2006, J. Geophys. Res.Oceans, 113, C08004, https://doi.org/10.1029/2007jc004551, 2008.

Asmi, E., Frey, A., Virkkula, A., Ehn, M., Manninen, H. E., Timonen, H., Tolonen-Kivimäki, O., Aurela, M., Hillamo, R., and Kulmala, M.: Hygroscopicity and chemical composition of Antarctic sub-micrometre aerosol particles and observations of new particle formation, Atmos. Chem. Phys., 10, 4253-4271, https://doi.org/10.5194/acp-10-4253-2010, 2010.

Asmi, E., Neitola, K., Teinila, K., Rodriguez, E., Virkkula, A., Backman, J., Bloss, M., Jokela, J., Lihavainen, H., De Leeuw, G., Paatero, J., Aaltonen, V., Mei, M., Gambarte, G., Copes, G., Albertini, M., Fogwill, G. P., Ferrara, J., Barlasina, M. E., and Sanchez, R.: Primary sources control the variability of aerosol optical properties in the Antarctic Peninsula, Tellus B, 70, 1, https://doi.org/10.1080/16000889.2017.1414571, 2018.

Attwood, A. R., Washenfelder, R. A., Brock, C. A., Hu, W., Baumann, K., Campuzano-Jost, P., Day, D. A., Edgerton, E. S., Murphy, D. M., Palm, B. B., McComiskey, A., Wagner, N. L., de Sa, S. S., Ortega, A., Martin, S. T., Jimenez, J. L., and Brown, S. S.: Trends in sulfate and organic aerosol mass in the Southeast U.S.: Impact on aerosol optical depth and radiative forcing, Geophys. Res. Lett., 41, 7701-7709, 10.1002/2014g1061669, 2014.

Barbaro, E., Kirchgeorg, T., Zangrando, R., Vecchiato, M., Piazza, R., Barbante, C., and Garnbaro, A.: Sugars in Antarctic aerosol, Atmos. Environ., 118, 135-144, https://doi.org/10.1016/j.atmosenv.2015.07.047, 2015a.

Barbaro, E., Zangrando, R., Vecchiato, M., Piazza, R., Cairns, W. R. L., Capodaglio, G., Barbante, C., and Gambaro, A.: Free amino acids in Antarctic aerosol: potential markers for the evolution and fate of marine aerosol, Atmos. Chem. Phys., 15, 5457-5469, https://doi.org/10.5194/acp-15-5457-2015, 2015b.

Barbaro, E., Zangrando, R., Kirchgeorg, T., Bazzano, A., Illuminati, S., Annibaldi, A., Rella, S., Truzzi, C., Grotti, M., Ceccarini, A., Malitesta, C., Scarponi, G., and Gambaro, A.: An integrated study of the chemical composition of Antarctic aerosol to investigate natural and anthropogenic sources, Environ. Chem., 13, 867-876, 10.1071/en16056, 2016.

Barbaro, E., Padoan, S., Kirchgeorg, T., Zangrando, R., Toscano, G., Barbante, C., and Gambaro, A.: Particle size distribution of inorganic and organic ions in coastal and inland Antarctic aerosol, Environ. Sci. Pollut. R., 24, 2724-2733, https://doi.org/10.1007/s11356-016-8042-x, 2017.

Beaton, A. E. and Tukey, J. W.: The Fitting of Power Series, Meaning Polynomials, Illustrated on Band-Spectroscopic Data, Technometrics, 16, 147-185, https://doi.org/10.2307/1267936, 1974.

Bintanja, R., Severijns, C., Haarsma, R., and Hazeleger, W.: The future of Antarctica's surface winds simulated by a high-resolution global climate model: 1. Model description and validation, J. Geophys. Res.-Atmos., 119, 7136-7159, https://doi.org/10.1002/2013jd020847, 2014.

Bodhaine, B. A.: Aerosol measurements at four background sites, J. Geophys. Res.-Oceans, 88, 10753-10768, 1983.

Bodhaine, B. A., Deluisi, J. J., Harris, J. M., Houmere, P., and Bauman, S.: Aerosol measurements at the South Pole, Tellus B, 38 , 223-235, 1986.

Bromwich, D. H., Nicolas, J. P., Monaghan, A. J., Lazzara, M. A., Keller, L. M., Weidner, G. A., and Wilson, A. B.: Central West Antarctica among the most rapidly warming regions on Earth, Nat. Geosci., 6, 139-145, https://doi.org/10.1038/ngeo1671, 2013.

Cadle, R. D., Fischer, W. H., Frank, E. R., and Lodge, J. P.: Particles in Antarctic Atmosphere, J. Atmos. Sci., 25, 100-103, https://doi.org/10.1175/15200469(1968)025<0100:pitaa>2.0.co;2, 1968.

Charbouillot, T., Gorini, S., Voyard, G., Parazols, M., Brigante, M., Deguillaume, L., Delort, A. M., and Mailhot, G.: Mechanism of carboxylic acid photooxidation in atmospheric aqueous phase: Formation, fate and reactivity, Atmos. Environ., 56, 1-8, https://doi.org/10.1016/j.atmosenv.2012.03.079, 2012

Cheung, K. L., Ntziachristos, L., Tzamkiozis, T., Schauer, J. J., Samaras, Z., Moore, K. F., and Sioutas, C.: Emissions of Particulate Trace Elements, Metals and Organic Species from Gasoline, Diesel, and Biodiesel Passenger Vehicles and Their Relation to Oxidative Potential, Aerosol Sci. Tech., 44, 500-513, https://doi.org/10.1080/02786821003758294, 2010.

Claeys, M., Szmigielski, R., Kourtchev, I., Van der Veken, P., Vermeylen, R., Maenhaut, W., Jaoui, M., Kleindienst, T. E., Lewandowski, M., and Offenberg, J. H.: Hydroxydicarboxylic acids: markers for secondary organic aerosol from the photooxidation of $\alpha$-pinene, Environ. Sci. Technol., 41, 1628-1634, 2007.

Cowie, G. L. and Hedges, J. I.: Sources and reactivities of amino acids in a coastal marine environment, Limnol. Oceanogr., 37, 703-724, https://doi.org/10.4319/1o.1992.37.4.0703, 1992.

Croft, B., Martin, R. V., Leaitch, W. R., Tunved, P., Breider, T. J., D'Andrea, S. D., and Pierce, J. R.: Processes controlling the annual cycle of Arctic aerosol number and size distributions, Atmos. Chem. Phys., 16, 3665-3682, https://doi.org/10.5194/acp16-3665-2016, 2016a.

Croft, B., Wentworth, G. R., Martin, R. V., Leaitch, W. R., Murphy, J. G., Murphy, B. N., Kodros, J. K., Abbatt, J. P. D., and Pierce, J. R.: Contribution of Arctic seabird-colony ammonia to atmospheric particles and cloud-albedo radiative effect, Nat. Commun., 7, 13444, https://doi.org/10.1038/ncomms13444, $2016 \mathrm{~b}$. 
Dall'Osto, M., Ceburnis, D., Monahan, C., Worsnop, D. R., Bialek, J., Kulmala, M., Kurten, T., Ehn, M., Wenger, J., Sodeau, J., Healy, R., and O'Dowd, C.: Nitrogenated and aliphatic organic vapors as possible drivers for marine secondary organic aerosol growth, J. Geophys. Res.-Atmos., 117, D12311, https://doi.org/10.1029/2012jd017522, 2012.

Dall'Osto, M., Ovadnevaite, J., Paglione, M., Beddows, D. C. S., Ceburnis, D., Cree, C., Cortes, P., Zamanillo, M., Nunes, S. O., Perez, G. L., Ortega-Retuerta, E., Emelianov, M., Vaque, D., Marrase, C., Estrada, M., Sala, M. M., Vidal, M., Fitzsimons, M. F., Beale, R., Airs, R., Rinaldi, M., Decesari, S., Facchini, M. C., Harrison, R. M., O’Dowd, C., and Simo, R.: Antarctic sea ice region as a source of biogenic organic nitrogen in aerosols, Scientific Reports, 7, 6047, https://doi.org/10.1038/s41598-01706188-x, 2017.

Davis, L. S., Harcourt, R. G., and Bradshaw, C. J. A.: The winter migration of Adelie penguins breeding in the Ross Sea sector of Antarctica, Polar Biol., 24, 593-597, https://doi.org/10.1007/s003000100256, 2001.

Defelice, T. P., Saxena, V. K., and Yu, S. C.: On the measurements of cloud condensation nuclei at Palmer Station, Antarctica, Atmos. Environ., 31, 4039-4044, https://doi.org/10.1016/s13522310(97)00250-1, 1997.

Domine, F., Sparapani, R., Ianniello, A., and Beine, H. J.: The origin of sea salt in snow on Arctic sea ice and in coastal regions, Atmos. Chem. Phys., 4, 2259-2271, https://doi.org/10.5194/acp4-2259-2004, 2004.

Draxier, R. R. and Hess, G. D.: An overview of the HYSPLIT_4 modelling system for trajectories, dispersion and deposition, Aust. Meteorol. Mag., 47, 295-308, 1998.

Frossard, A. A., Shaw, P. M., Russell, L. M., Kroll, J. H., Canagaratna, M. R., Worsnop, D. R., Quinn, P. K., and Bates, T. S.: Springtime Arctic haze contributions of submicron organic particles from European and Asian combustion sources, J. Geophys. Res.-Atmos., 116, D05205, https://doi.org/10.1029/2010jd015178, 2011.

Frossard, A. A., Russell, L. M., Keene, W. C., Kieber, D. J., Quinn, P. K., and Bates, T. S.: Regional Signatures in the Organic Composition of Marine Aerosol Particles, in: AIP Conference Proceedings, 19th International Conference on Nucleation and Atmospheric Aerosols (ICNAA), Colorado State Univ, Ctr Arts, Fort Collins, CO, 2013, 543-546, 2013.

Frossard, A. A., Russell, L. M., Burrows, S. M., Elliott, S. M., Bates, T. S., and Quinn, P. K.: Sources and composition of submicron organic mass in marine aerosol particles, J. Geophys. Res.-Atmos., 119, 12977-13003, https://doi.org/10.1002/2014jd021913, 2014a.

Frossard, A. A., Russell, L. M., Massoli, P., Bates, T. S., and Quinn, P. K.: Side-by-Side Comparison of Four Techniques Explains the Apparent Differences in the Organic Composition of Generated and Ambient Marine Aerosol Particles, Aerosol Sci. Tech., 48, V-X, https://doi.org/10.1080/02786826.2013.879979, 2014b.

Gagosian, R. B. and Stuermer, D. H.: The cycling of biogenic compounds and their diagenetically transformed products in seawater, Mar. Chem., 5, 605-632, 1977.

Giordano, M. R., Kalnajs, L. E., Avery, A., Goetz, J. D., Davis, S. M., and DeCarlo, P. F.: A missing source of aerosols in Antarctica - beyond long-range transport, phytoplankton, and photochem- istry, Atmos. Chem. Phys., 17, 1-20, https://doi.org/10.5194/acp17-1-2017, 2017.

Gordon, M. and Taylor, P. A.: Measurements of blowing snow, Part I: Particle shape, size distribution, velocity, and number flux at Churchill, Manitoba, Canada, Cold Reg. Sci. Technol., 55, 6374, https://doi.org/10.1016/j.coldregions.2008.05.001, 2009.

Goring, D. G. and Nikora, V. I.: Despiking acoustic Doppler velocimeter data, J. Hydraul. Eng.-ASCE, 128, 117-126, https://doi.org/10.1061/(asce)0733-9429(2002)128:1(117), 2002.

Gras, J. L.: Condensation nucleus size distribution at Mawson, Antarctica - microphysics and chemistry, Atmos. Environ. A-Gen., 27, 1427-1434, https://doi.org/10.1016/09601686(93)90128-1, 1993.

Guzman-Morales, J., Frossard, A. A., Corrigan, A. L., Russell, L. M., Liu, S., Takahama, S., Taylor, J. W., Allan, J., Coe, H., Zhao, Y., and Goldstein, A. H.: Estimated contributions of primary and secondary organic aerosol from fossil fuel combustion during the CalNex and Cal-Mex campaigns, Atmos. Environ., 88, 330-340, 10.1016/j.atmosenv.2013.08.047, 2014.

Hansen, A. D. A., Bodhaine, B. A., Dutton, E. G., and Schnell, R. C.: Aerosol Black Carbon Measurements at the South-Pole Initial Results, 1986-1987, Geophys. Res. Lett., 15, 1193-1196, https://doi.org/10.1029/GL015i011p01193, 1988.

Hansen, A. D. A., Lowenthal, D. H., Chow, J. C., and Watson, J. G.: Black carbon aerosol at McMurdo station, Antarctica, J. Air Waste Manage., 51, 593-600, 2001.

Hara, K., Osada, K., Kido, M., Hayashi, M., Matsunaga, K., Iwasaka, Y., Yamanouchi, T., Hashida, G., and Fukatsu, T.: Chemistry of sea-salt particles and inorganic halogen species in Antarctic regions: Compositional differences between coastal and inland stations, J. Geophys. Res.-Atmos., 109, D20208, https://doi.org/10.1029/2004JD004713, 2004.

Hara, K., Osada, K., Kido, M., Matsunaga, K., Iwasaka, Y., Hashida, G., and Yamanouchi, T.: Variations of constituents of individual sea-salt particles at Syowa station, Antarctica, Tellus B, 57, 230-246, https://doi.org/10.1111/j.16000889.2005.00142.x, 2005.

Hara, K., Osada, K., Yabuki, M., Hashida, G., Yamanouchi, T., Hayashi, M., Shiobara, M., Nishita, C., and Wada, M. Haze episodes at Syowa Station, coastal Antarctica: Where did they come from?, J. Geophys. Res.-Atmos., 115, D14205, https://doi.org/10.1029/2009JD012582, 2010.

Harder, S., Warren, S. G., and Charlson, R. J.: Sulfate in air and snow at the South Pole: Implications for transport and deposition at sites with low snow accumulation, J. Geophys. Res.-Atmos., 105, 22825-22832, 2000.

Hartigan, J. A. and Wong, M. A.: Algorithm AS 136: A k-means clustering algorithm, J. Roy. Stat. Soc. C-App., 28, 100-108, 1979.

Hawkins, L. N. and Russell, L.: Polysaccharides, Proteins, and Phytoplankton Fragments: Four Chemically Distinct Types of Marine Primary Organic Aerosol Classified by Single Particle Spectromicroscopy, Adv. Meteorol., 14, 612132, https://doi.org/10.1155/2010/612132, 2010.

Hofmann, D.: Balloon-borne measurements of middle atmosphere aerosols and trace gases in Antarctica, Rev. Geophy., 26, 113130, 1988. 
Hofmann, D. J., Rosen, J. M., Harder, J. A., and Rolf, S. R.: Ozone and aerosol measurements in the springtime Antarctic Stratosphere in 1985, Geophys. Res. Lett., 13, 1252-1255, https://doi.org/10.1029/GL013i012p01252, 1986.

Hogan, A. W.: Antarctic aerosols, J. Appl. Meteorol., 14, 550-559, https://doi.org/10.1175/1520-0450(1975)014<0550:aa>2.0.co;2, 1975.

Hogan, A. W. and Barnard, S.: Seasonal and frontal variation in Antarctic aerosol concentrations, J. Appl. Meteorol., 17, 1458-1465, https://doi.org/10.1175/15200450(1978)017<1458:safvia>2.0.co;2, 1978 .

Holland, P. R.: The seasonality of Antarctic sea ice trends, Geophys. Res. Lett., 41, 4230-4237, https://doi.org/10.1002/2014g1060172, 2014.

Huang, J. and Jaeglé, L.: Wintertime enhancements of sea salt aerosol in polar regions consistent with a sea ice source from blowing snow, Atmos. Chem. Phys., 17, 3699-3712, https://doi.org/10.5194/acp-17-3699-2017, 2017.

IPCC: Summary for policymakers in climate change 2013: the physical science basis, contribution of working group I to the fifth assessment report of the intergovernmental panel on climate change, edited by: Stocker, T. F., Qin, D., Plattner, G. K., Tignor, M., Allen, S. K., Boschung, J., Nauels, A., Xia, Y., Bex, V., and Midgley, P. M., Cambridge Univ Press, Cambridge, UK and New York, 2013.

Jourdain, B. and Legrand, M.: Year-round records of bulk and size-segregated aerosol composition and $\mathrm{HCl}$ and $\mathrm{HNO}_{3}$ levels in the Dumont d'Urville (coastal Antarctica) atmosphere: Implications for sea-salt aerosol fractionation in the winter and summer, J. Geophys. Res.-Atmos., 107, 4645, https://doi.org/10.1029/2002jd002471, 2002.

Jourdain, B., Preunkert, S., Cerri, O., Castebrunet, H., Udisti, R., and Legrand, M.: Year-round record of sizesegregated aerosol composition in central Antarctica (Concordia station): Implications for the degree of fractionation of sea-salt particles, J. Geophys. Res.-Atmos., 113, D14308, https://doi.org/10.1029/2007jd009584, 2008.

Kalnajs, L. E., Avallone, L. M., and Toohey, D. W.: Correlated measurements of ozone and particulates in the Ross Island region, Antarctica, Geophys. Res. Lett., 40, 6319-6323, 10.1002/2013g1058422, 2013.

Kawamura, K. and Gagosian, R. B.: Implications of omegaoxocarboxylic acids in the remote marine atmosphere for photooxidation of unsaturated fatty acids, Nature, 325, 330-332, https://doi.org/10.1038/325330a0, 1987.

Khan, A. L., McMeeking, G. R., Schwarz, J. P., Xian, P., Welch, K. A., Berry Lyons, W., and McKnight, D. M.: Near-Surface Refractory Black Carbon Observations in the Atmosphere and Snow in the McMurdo Dry Valleys, Antarctica, and Potential Impacts of Foehn Winds, J. Geophys. Res.-Atmos., 123, 2877-2887, 2018.

Kim, J., Yoon, Y. J., Gim, Y., Kang, H. J., Choi, J. H., Park, K.-T., and Lee, B. Y.: Seasonal variations in physical characteristics of aerosol particles at the King Sejong Station, Antarctic Peninsula, Atmos. Chem. Phys., 17, 12985-12999, https://doi.org/10.5194/acp-17-12985-2017, 2017.

Korhonen, H., Carslaw, K. S., Spracklen, D. V., Mann, G. W., and Woodhouse, M. T.: Influence of oceanic dimethyl sulfide emissions on cloud condensation nuclei concentrations and seasonality over the remote Southern Hemisphere oceans: A global model study, J. Geophys. Res.-Atmos., 113, D15204, https://doi.org/10.1029/2007jd009718, 2008.

Kuznetsova, M., Lee, C., and Aller, J.: Characterization of the proteinaceous matter in marine aerosols, Mar. Chem., 96, 359-377, https://doi.org/10.1016/j.marchem.2005.03.007, 2005.

Kyrö, E.-M., Kerminen, V.-M., Virkkula, A., Dal Maso, M., Parshintsev, J., Ruíz-Jimenez, J., Forsström, L., Manninen, H. E., Riekkola, M.-L., Heinonen, P., and Kulmala, M.: Antarctic new particle formation from continental biogenic precursors, Atmos. Chem. Phys., 13, 3527-3546, https://doi.org/10.5194/acp13-3527-2013, 2013.

Lambeck, K., Esat, T. M., and Potter, E. K.: Links between climate and sea levels for the past three million years, Nature, 419, 199206, https://doi.org/10.1038/nature01089, 2002.

Leaitch, W. R., Russell, L. M., Liu, J., Kolonjari, F., Toom, D., Huang, L., Sharma, S., Chivulescu, A., Veber, D., and Zhang, W.: Organic functional groups in the submicron aerosol at $82.5^{\circ} \mathrm{N}$, $62.5^{\circ} \mathrm{W}$ from 2012 to 2014, Atmos. Chem. Phys., 18, 32693287, https://doi.org/10.5194/acp-18-3269-2018, 2018.

Legrand, M., Ducroz, F., Wagenbach, D., Mulvaney, R., and Hall, J.: Ammonium in coastal Antarctic aerosol and snow: Role of polar ocean and penguin emissions, J. Geophys. Res.-Atmos., 103, 11043-11056, https://doi.org/10.1029/97jd01976, 1998.

Legrand, M., Gros, V., Preunkert, S., Sarda-Esteve, R., Thierry, A. M., Pepy, G., and Jourdain, B.: A reassessment of the budget of formic and acetic acids in the boundary layer at Dumont d'Urville (coastal Antarctica): The role of penguin emissions on the budget of several oxygenated volatile organic compounds, J. Geophys. Res.-Atmos., 117, D06308, https://doi.org/10.1029/2011jd017102, 2012.

Legrand, M., Preunkert, S., Weller, R., Zipf, L., Elsässer, C., Merchel, S., Rugel, G., and Wagenbach, D.: Year-round record of bulk and size-segregated aerosol composition in central Antarctica (Concordia site) - Part 2: Biogenic sulfur (sulfate and methanesulfonate) aerosol, Atmos. Chem. Phys., 17, 1405514073, https://doi.org/10.5194/acp-17-14055-2017, 2017a.

Legrand, M., Preunkert, S., Wolff, E., Weller, R., Jourdain, B., and Wagenbach, D.: Year-round records of bulk and sizesegregated aerosol composition in central Antarctica (Concordia site) - Part 1: Fractionation of sea-salt particles, Atmos. Chem. Phys., 17, 14039-14054, https://doi.org/10.5194/acp-17-140392017, $2017 \mathrm{~b}$.

Lin, Y.-C., Tsai, C.-J., Wu, Y.-C., Zhang, R., Chi, K.-H., Huang, Y.-T., Lin, S.-H., and Hsu, S.-C.: Characteristics of trace metals in traffic-derived particles in Hsuehshan Tunnel, Taiwan: size distribution, potential source, and fingerprinting metal ratio, Atmos. Chem. Phys., 15, 4117-4130, https://doi.org/10.5194/acp15-4117-2015, 2015.

Liu, J., Lewis, S., and Russell, L. M.: Organic and Elemental Composition of Submicron Aerosol Particles during AWARE at McMurdo Station, Antarctica, https://doi.org/10.6075/J0WM1BKV, 2018.

Loureiro, A., Vasconcellos, M., and Pereira, E.: Trace element determination in aerosols from the Antarctic Peninsula by neutron activation analysis, J. Radioanal. Nucl. Ch., 159, 21-28, 1992.

Lyver, P. O., Barron, M., Barton, K. J., Ainley, D. G., Pollard, A., Gordon, S., McNeill, S., Ballard, G., and Wilson, P. R.: Trends in the Breeding Population of Adelie Penguins in the Ross Sea, 1981-2012: A Coincidence of 
Climate and Resource Extraction Effects, Plos One, 9, https://doi.org/10.1371/journal.pone.0091188, 2014.

Mace, K. A., Duce, R. A., and Tindale, N. W.: Organic nitrogen in rain and aerosol at Cape Grim, Tasmania, Australia, J. Geophys. Res.-Atmos., 108, 4338, https://doi.org/10.1029/2002jd003051, 2003a.

Mace, K. A., Kubilay, N., and Duce, R. A.: Organic nitrogen in rain and aerosol in the eastern Mediterranean atmosphere: An association with atmospheric dust, J. Geophys. Res.-Atmos., 108, 4320, https://doi.org/10.1029/2002jd002997, 2003b.

Mandalakis, M., Apostolaki, M., Tziaras, T., Polymenakou, P., and Stephanou, E. G.: Free and combined amino acids in marine background atmospheric aerosols over the Eastern Mediterranean, Atmos. Environ., 45, 1003-1009, https://doi.org/10.1016/j.atmosenv.2010.10.046, 2011.

Maria, S. F., Russell, L. M., Turpin, B. J., and Porcja, R. J.: FTIR measurements of functional groups and organic mass in aerosol samples over the Caribbean, Atmos. Environ., 36, 5185-5196, https://doi.org/10.1016/s1352-2310(02)00654-4, 2002.

Matsumoto, K. and Uematsu, M.: Free amino acids in marine aerosols over the western North Pacific Ocean, Atmos. Environ., 39, 2163-2170, https://doi.org/10.1016/j.atmosenv.2004.12.022, 2005.

Mazzera, D. M., Lowenthal, D. H., Chow, J. C., and Watson, J. G.: Sources of $\mathrm{PM}_{10}$ and sulfate aerosol at McMurdo station, Antarctica, Chemosphere, 45, 347-356, https://doi.org/10.1016/s0045-6535(00)00591-9, 2001a.

Mazzera, D. M., Lowenthal, D. H., Chow, J. C., Watson, J. G., and Grubisic, V.: $\mathrm{PM}_{10}$ measurements at McMurdo Station, Antarctica, Atmos. Environ., 35, 1891-1902, https://doi.org/10.1016/s1352-2310(00)00409-x, 2001 b.

McCoy, D. T., Burrows, S. M., Wood, R., Grosvenor, D. P., Elliott, S. M., Ma, P.-L., Rasch, P. J., and Hartmann, D. L.: Natural aerosols explain seasonal and spatial patterns of Southern Ocean cloud albedo, Sci. Adv., 1, e1500157, https://doi.org/10.1126/sciadv.1500157, 2015.

McNeill, V. F.: Aqueous Organic Chemistry in the Atmosphere: Sources and Chemical Processing of Organic Aerosols, Environ. Sci. Technol., 49, 1237-1244, https://doi.org/10.1021/es5043707, 2015.

Milne, P. J. and Zika, R. G.: Amino-acid nitrogen in atmospheric aerosols - occurrence, sources and photochemical modification, J. Atmos. Chem., 16, 361-398, https://doi.org/10.1007/bf01032631, 1993.

Minikin, A., Legrand, M., Hall, J., Wagenbach, D., Kleefeld, C., Wolff, E., Pasteur, E. C., and Ducroz, F.: Sulfur-containing species (sulfate and methanesulfonate) in coastal Antarctic aerosol and precipitation, J. Geophys. Res.-Atmos. 103, 1097510990, 1998.

Mishra, V. K., Kim, K.-H., Hong, S., and Lee, K.: Aerosol composition and its sources at the King Sejong Station, Antarctic peninsula, Atmos. Environ., 38, 4069-4084, 2004

Modini, R. L., Frossard, A. A., Ahlm, L., Russell, L. M., Corrigan, C. E., Roberts, G. C., Hawkins, L. N., Schroder, J. C., Bertram, A. K., Zhao, R., Lee, A. K. Y., Abbatt, J. P. D., Lin, J., Nenes, A., Wang, Z., Wonaschutz, A., Sorooshian, A., Noone, K. J., Jonsson, H., Seinfeld, J. H., Toom-Sauntry, D., Macdonald, A. M., and Leaitch, W. R.: Primary marine aerosol-cloud interactions off the coast of California, J. Geophys. Res.-Atmos., 120, 42824303, https://doi.org/10.1002/2014jd022963, 2015.

Olson, M. R., Garcia, M. V., Robinson, M. A., Van Rooy, P., Dietenberger, M. A., Bergin, M., and Schauer, J. J.: Investigation of black and brown carbon multiple-wavelengthdependent light absorption from biomass and fossil fuel combustion source emissions, J. Geophys. Res.-Atmos., 120, 66826697, https://doi.org/10.1002/2014jd022970, 2015.

Ondov, J. M., Gladney, E. S., Zoller, W. H., Duce, R. A., and Jones, A. G.: Atmospheric particulates at South-Pole station, Antarct. J. US, 8, 182-183, 1973a.

Ondov, J. M., Gladney, E. S., Zoller, W. H., Duce, R. A., and Jones, A. G.: Atmospheric particulates at South-Pole station, Antarct. J. US, 8, 182-183, 1973 b.

Paatero, P.: Least squares formulation of robust non-negative factor analysis, Chemometr. Intell. Lab., 37, 23-35, https://doi.org/10.1016/s0169-7439(96)00044-5, 1997.

Paatero, P. and Tapper, U.: Positive Matrix Factorization: A Non-Negative Factor Model with Optimal Utilization of Error Estimates of Data Values, Environmetrics, 5, 111-126, https://doi.org/10.1002/env.3170050203, 1994.

Parungo, F., Bodhaine, B., and Bortniak, J.: Seasonal variation in Antarctic aerosol, J. Aerosol Sci., 12, 491-504, https://doi.org/10.1016/0021-8502(81)90052-5, 1981.

Peng, J., Hu, M., Guo, S., Du, Z., Shang, D., Zheng, J., Zheng, J., Zeng, L., Shao, M., Wu, Y., Collins, D., and Zhang, R.: Ageing and hygroscopicity variation of black carbon particles in Beijing measured by a quasi-atmospheric aerosol evolution study (QUALITY) chamber, Atmos. Chem. Phys., 17, 10333-10348, https://doi.org/10.5194/acp-17-10333-2017, 2017.

Petters, M. D. and Kreidenweis, S. M.: A single parameter representation of hygroscopic growth and cloud condensation nucleus activity, Atmos. Chem. Phys., 7, 1961-1971, https://doi.org/10.5194/acp-7-1961-2007, 2007.

Polissar, A. V., Hopke, P. K., Paatero, P., Kaufmann, Y. J., Hall, D. K., Bodhaine, B. A., Dutton, E. G., and Harris, J. M.: The aerosol at Barrow, Alaska: long-term trends and source locations, Atmos. Environ., 33, 2441-2458, https://doi.org/10.1016/s13522310(98)00423-3, 1999.

Price, D. J., Chen, C.-L., Russell, L. M., Lamjiri, M. A., Betha, R., Sanchez, K., Liu, J., Lee, A. K. Y., and Cocker, D. R.: More unsaturated, cooking-type hydrocarbonlike organic aerosol particle emissions from renewable diesel compared to ultra low sulfur diesel in at-sea operations of a research vessel, Aerosol Sci. Tech., 51, 135-146, https://doi.org/10.1080/02786826.2016.1238033, 2017.

Read, K. A., Lewis, A. C., Bauguitte, S., Rankin, A. M., Salmon, R. A., Wolff, E. W., Saiz-Lopez, A., Bloss, W. J., Heard, D. E., Lee, J. D., and Plane, J. M. C.: DMS and MSA measurements in the Antarctic Boundary Layer: impact of $\mathrm{BrO}$ on MSA production, Atmos. Chem. Phys., 8, 2985-2997, https://doi.org/10.5194/acp8-2985-2008, 2008.

Rickard, A. R., Wyche, K. P., Metzger, A., Monks, P. S., Ellis, A. M., Dommen, J., Baltensperger, U., Jenkin, M. E., and Pilling, M. J.: Gas phase precursors to anthropogenic secondary organic aerosol Using the Master Chemical Mechanism to probe detailed observations of 1,3,5trimethylbenzene photo-oxidation, Atmos. Environ., 44, 54235433, https://doi.org/10.1016/j.atmosenv.2009.09.043, 2010. 
Rickards, A. M. J., Miles, R. E. H., Davies, J. F., Marshall, F. H., and Reid, J. P.: Measurements of the Sensitivity of Aerosol Hygroscopicity and the kappa Parameter to the O/C Ratio, J. Phys. Chem. A, 117, 14120-14131, https://doi.org/10.1021/jp407991n, 2013.

Riddick, S. N., Dragosits, U., Blackall, T. D., Daunt, F., Wanless, S., and Sutton, M. A.: The global distribution of ammonia emissions from seabird colonies, Atmos. Environ., 55, 319-327, https://doi.org/10.1016/j.atmosenv.2012.02.052, 2012.

Russell, L. M.: Aerosol organic-mass-to-organic-carbon ratio measurements, Environ. Sci. Technol., 37, 2982-2987, 10.1021/es026123w, 2003.

Russell, L. M. and Shaw, G. E.: Arctic and Antarctic/Arctic Haze, in: Encyclopedia of Atmospheric Sciences, 2nd Edn., edited by: North, G., Pyle, J., and Zhang, F., Elsevier, UK and USA, 116$121,2015$.

Russell, L. M., Bahadur, R., Hawkins, L. N., Allan, J., Baumgardner, D., Quinn, P. K., and Bates, T. S.: Organic aerosol characterization by complementary measurements of chemical bonds and molecular fragments, Atmos. Environ., 43, 61006105, https://doi.org/10.1016/j.atmosenv.2009.09.036, 2009.

Russell, L. M., Hawkins, L. N., Frossard, A. A., Quinn, P. K., and Bates, T. S.: Carbohydrate-like composition of submicron atmospheric particles and their production from ocean bubble bursting, P. Natl. Acad. Sci. USA, 107, 6652-6657, https://doi.org/10.1073/pnas.0908905107, 2010.

Russell, L. M., Bahadur, R., and Ziemann, P. J.: Identifying organic aerosol sources by comparing functional group composition in chamber and atmospheric particles, P. Natl. Acad. Sci. USA, 108, 3516-3521, https://doi.org/10.1073/pnas.1006461108, 2011.

Saliba, G., Saleh, R., Zhao, Y. L., Presto, A. A., Larnbe, A. T., Frodin, B., Sardar, S., Maldonado, H., Maddox, C., May, A. A., Drozd, G. T., Goldstein, A. H., Russell, L. M., Hagen, F., and Robinson, A. L.: Comparison of Gasoline Direct-Injection (GDI) and Port Fuel Injection (PFI) Vehicle Emissions: Emission Certification Standards, Cold-Start, Secondary Organic Aerosol Formation Potential, and Potential Climate Impacts, Environ. Sci. Technol., 51, 6542-6552, https://doi.org/10.1021/acs.est.6b06509, 2017.

Savoie, D., Prospero, J., Larsen, R., Huang, F., Izaguirre, M., Huang, T., Snowdon, T., Custals, L., and Sanderson, C.: Nitrogen and sulfur species in Antarctic aerosols at Mawson, Palmer station, and Marsh (King George Island), J. Atmos. Chem., 17, 95-122, 1993.

Sax, M., Zenobi, R., Baltensperger, U., and Kalberer, M.: Time resolved infrared spectroscopic analysis of aerosol formed by photo-oxidation of 1,3,5-trimethylbenzene and alpha-pinene, Aerosol Sci. Tech., 39, 822-830, https://doi.org/10.1080/02786820500257859, 2005.

Saxena, V. and Ruggiero, F.: Aerosol measurements at Palmer Station, Antarctica, Contributions to Antarctic Research, I, 1-5, 1990.

Scalabrin, E., Zangrando, R., Barbaro, E., Kehrwald, N. M., Gabrieli, J., Barbante, C., and Gambaro, A.: Amino acids in Arctic aerosols, Atmos. Chem. Phys., 12, 10453-10463, https://doi.org/10.5194/acp-12-10453-2012, 2012.

Schmale, J., Schneider, J., Nemitz, E., Tang, Y. S., Dragosits, U., Blackall, T. D., Trathan, P. N., Phillips, G. J., Sutton, M., and Braban, C. F.: Sub-Antarctic marine aerosol: dominant contri- butions from biogenic sources, Atmos. Chem. Phys., 13, 86698694, https://doi.org/10.5194/acp-13-8669-2013, 2013.

Schmidt, R. A.: Estimates of threshold windspeed from particle sizes in blowing snow, Cold Reg. Sci. Technol., 4, 187-193, https://doi.org/10.1016/0165-232x(81)90003-3, 1981.

Shaw, P. M., Russell, L. M., Jefferson, A., and Quinn, P. K.: Arctic organic aerosol measurements show particles from mixed combustion in spring haze and from frost flowers in winter, Geophys. Res. Lett., 37, L10803, https://doi.org/10.1029/2010g1042831, 2010.

Shi, J. H., Gao, H. W., Qi, J. H., Zhang, J., and Yao, X. H.: Sources, compositions, and distributions of water-soluble organic nitrogen in aerosols over the China Sea, J. Geophys. Res.-Atmos., 115, D17303, https://doi.org/10.1029/2009jd013238, 2010.

Solomon, S., Sanders, R. W., Jakoubek, R. O., Arpag, K. H., Stephens, S. L., Keys, J. G., and Garcia, R. R.: Visible and near-ultraviolet spectroscopy at McMurdo-station, Antarctica. 10. Reductions of stratospheric $\mathrm{NO}_{2}$ Due to Pinatubo aerosols, J. Geophys. Res.-Atmos., 99, 3509-3516, https://doi.org/10.1029/93jd03088, 1994.

Steig, E. J., Schneider, D. P., Rutherford, S. D., Mann, M. E., Comiso, J. C., and Shindell, D. T.: Warming of the Antarctic icesheet surface since the 1957 International Geophysical Year, Nature, 457, 459-462, https://doi.org/10.1038/nature07669, 2009.

Stephanou, E. G. and Stratigakis, N.: Oxocarboxylic and $\alpha, \omega$ dicarboxylic acids: photooxidation products of biogenic unsaturated fatty acids present in urban aerosols, Environ. Sci. Technol., 27, 1403-1407, 1993.

Stohl, A.: Characteristics of atmospheric transport into the Arctic troposphere, J. Geophys. Res.-Atmos., 111, D11306, https://doi.org/10.1029/2005jd006888, 2006.

Stohl, A. and Sodemann, H.: Characteristics of atmospheric transport into the Antarctic troposphere, J. Geophys. Res.-Atmos., 115, D02305, https://doi.org/10.1029/2009jd012536, 2010.

Su, H., Rose, D., Cheng, Y. F., Gunthe, S. S., Massling, A., Stock, M., Wiedensohler, A., Andreae, M. O., and Pöschl, U.: Hygroscopicity distribution concept for measurement data analysis and modeling of aerosol particle mixing state with regard to hygroscopic growth and CCN activation, Atmos. Chem. Phys., 10, 7489-7503, https://doi.org/10.5194/acp-10-7489-2010, 2010.

Takahama, S., Johnson, A., and Russell, L. M.: Quantification of carboxylic and carbonyl functional groups in organic aerosol infrared absorbance spectra, Aerosol Sci. Tech., 47, 310-325, https://doi.org/10.1080/02786826.2012.752065, 2013.

Thomas, D. N. and Dieckmann, G. S.: Sea ice: an introduction to its physics, chemistry, biology and geology, John Wiley \& Sons, 2008.

Tukey, J. W.: Exploratory Data Analysis, 1st Edn., Behavioral Science, Addison-Wesley, Reading, MA, 1977.

Udisti, R., Dayan, U., Becagli, S., Busetto, M., Frosini, D., Legrand, M., Lucarelli, F., Preunkert, S., Severi, M., Traversi, R., and Vitale, V.: Sea spray aerosol in central Antarctica. Present atmospheric behaviour and implications for paleoclimatic reconstructions, Atmos. Environ., 52, 109-120, https://doi.org/10.1016/j.atmosenv.2011.10.018, 2012.

Usher, C. R., Michel, A. E., and Grassian, V. H.: Reactions on mineral dust, Chem. Rev., 103, 4883-4939, https://doi.org/10.1021/cr020657y, 2003. 
Velleman, P. F.: Robust nonlinear data smoothers - definitions and recommendations, P. Natl. Acad. Sci. USA, 74, 434-436, https://doi.org/10.1073/pnas.74.2.434, 1977.

Violaki, K., Zarbas, P., and Mihalopoulos, N.: Long-term measurements of dissolved organic nitrogen (DON) in atmospheric deposition in the Eastern Mediterranean: Fluxes, origin and biogeochemical implications, Mar. Chem., 120, 179-186, https://doi.org/10.1016/j.marchem.2009.08.004, 2010.

Vu, D., Short, D., Karavalakis, G., Durbin, T. D., and AsaAwuku, A.: Will Aerosol Hygroscopicity Change with Biodiesel, Renewable Diesel Fuels and Emission Control Technologies?, Environ. Sci. Technol., 51, 1580-1586, https://doi.org/10.1021/acs.est.6b03908, 2017.

Wagenbach, D., Ducroz, F., Mulvaney, R., Keck, L., Minikin, A., Legrand, M., Hall, J. S., and Wolff, E. W.: Sea-salt aerosol in coastal Antarctic regions, J. Geophys. Res.-Atmos., 103, 1096110974, https://doi.org/10.1029/97jd01804, 1998.

Warburton, J. A.: Surface measurements of Aitken nuclei at McMurdo, Siple, Byrd, and South-pole stations, Antarct. J. US, 8, 236-236, 1973.

Weber, R. J., McMurry, P. H., Mauldin, L., Tanner, D. J., Eisele, F. L., Brechtel, F. J., Kreidenweis, S. M., Kok, G. L., Schillawski, R. D., and Baumgardner, D.: A study of new particle formation and growth involving biogenic and trace gas species measured during ACE 1, J. Geophys. Res.-Atmos., 103, 16385-16396, https://doi.org/10.1029/97jd02465, 1998.

Wedyan, M. A. and Preston, M. R.: The coupling of surface seawater organic nitrogen and the marine aerosol as inferred from enantiomer-specific amino acid analysis, Atmos. Environ., 42, 8698-8705, https://doi.org/10.1016/j.atmosenv.2008.04.038, 2008.

Weller, R. and Wagenbach, D.: Year-round chemical aerosol records in continental Antarctica obtained by automatic samplings, Tellus B, 59, 755-765, https://doi.org/10.1111/j.16000889.2007.00293.x, 2007.
Weller, R., Minikin, A., Petzold, A., Wagenbach, D., and König-Langlo, G.: Characterization of long-term and seasonal variations of black carbon $(\mathrm{BC})$ concentrations at Neumayer, Antarctica, Atmos. Chem. Phys., 13, 1579-1590, https://doi.org/10.5194/acp-13-1579-2013, 2013.

Wex, H., McFiggans, G., Henning, S., and Stratmann, F.: Influence of the external mixing state of atmospheric aerosol on derived CCN number concentrations, Geophys. Res. Lett., 37, L10805, https://doi.org/10.1029/2010gl043337, 2010.

Wyche, K. P., Monks, P. S., Ellis, A. M., Cordell, R. L., Parker, A. E., Whyte, C., Metzger, A., Dommen, J., Duplissy, J., Prevot, A. S. H., Baltensperger, U., Rickard, A. R., and Wulfert, F.: Gas phase precursors to anthropogenic secondary organic aerosol: detailed observations of 1,3,5-trimethylbenzene photooxidation, Atmos. Chem. Phys., 9, 635-665, https://doi.org/10.5194/acp-9635-2009, 2009.

Xu, G. J., Gao, Y., Lin, Q., Li, W., and Chen, L. Q.: Characteristics of water-soluble inorganic and organic ions in aerosols over the Southern Ocean and coastal East Antarctica during austral summer, J. Geophys. Res.-Atmos., 118, 13303-13318, https://doi.org/10.1002/2013jd019496, 2013.

Yang, X., Pyle, J. A., and Cox, R. A.: Sea salt aerosol production and bromine release: Role of snow on sea ice, Geophys. Res. Lett., 35, L16815, https://doi.org/10.1029/2008g1034536, 2008.

Zangrando, R., Barbaro, E., Vecchiato, M., Kehrwald, N. M., Barbante, C., and Gambaro, A.: Levoglucosan and phenols in Antarctic marine, coastal and plateau aerosols, Sci. Total Environ., 544, 606-616, https://doi.org/10.1016/j.scitotenv.2015.11.166, 2016. 